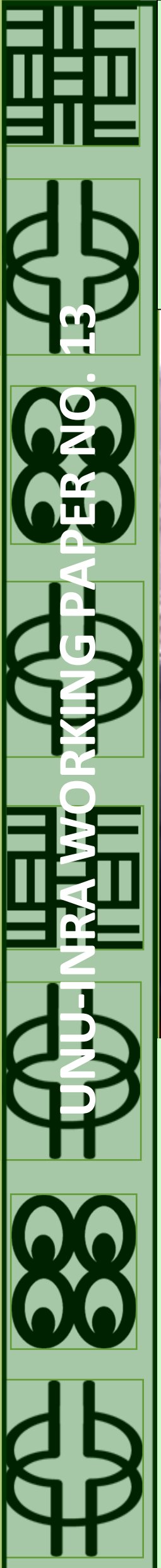

\title{
Environmental and Economic Burden of Sand Dredging on Artisanal Fishing in Lagos State, Nigeria
}

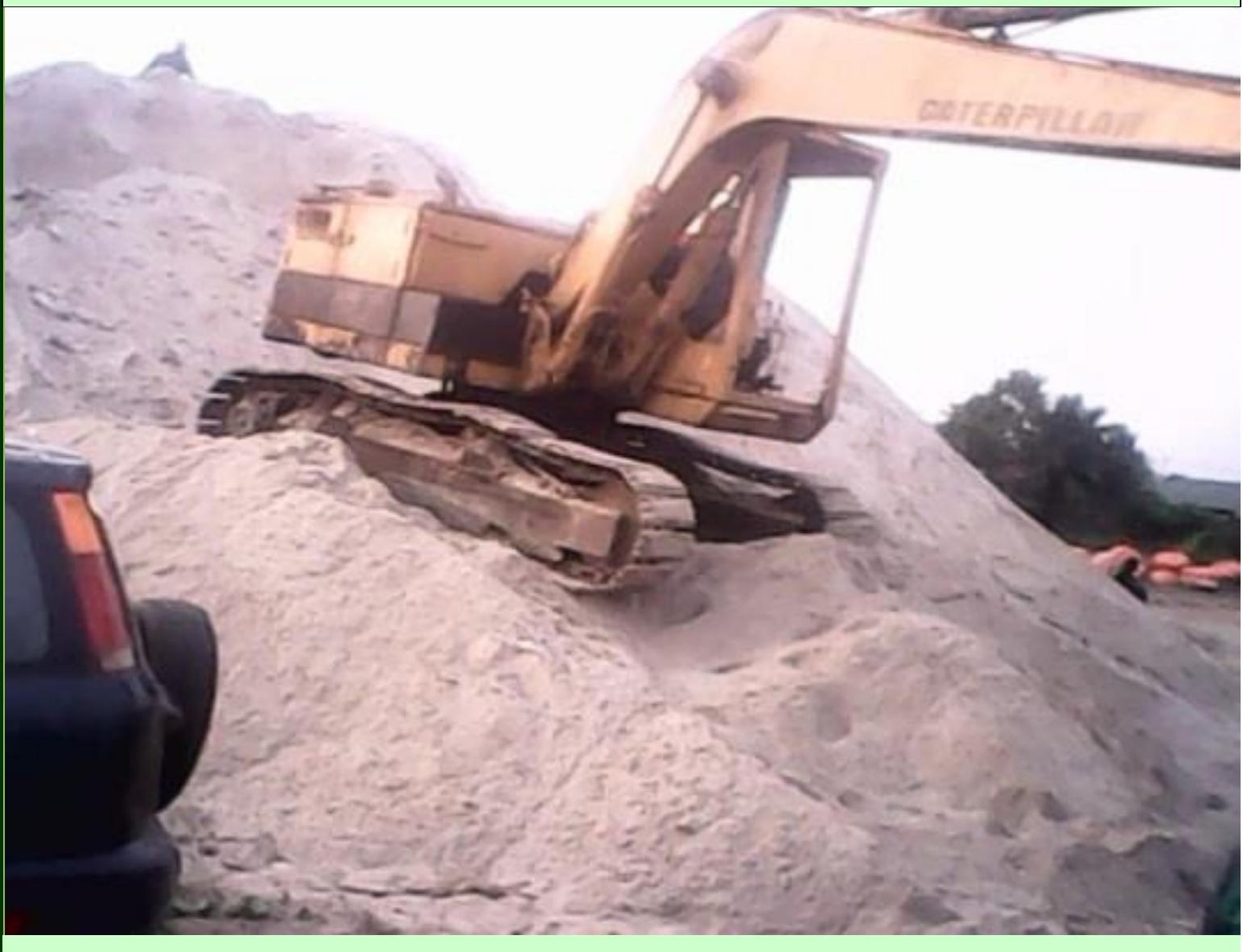

\section{Fatai Abiola Sowunmi}




\section{United Nations University \\ Institute for Natural Resources in Africa \\ (UNU-INRA)}

\section{Environmental and Economic Burden of Sand Dredging on Artisanal Fishing in Lagos State, Nigeria}

Fatai Abiola Sowunmi 


\section{UNITED NATIONS UNIVERSITY INSTITUTE FOR NATURAL RESOURCES IN AFRICA (UNU-INRA)}

Environmental and Economic Burden of Sand Dredging on Artisanal Fishing in Lagos State, Nigeria

Fatai Abiola Sowunmi 


\begin{abstract}
About UNU-INRA
The United Nations University Institute for Natural Resources in Africa (UNU-INRA) is the second Research and Training Centre / Programme established by the UN University. The mandate of the Institute is to promote the sustainable management of Africa's natural resources through research, capacity development, policy advice, knowledge sharing and transfer. The Institute is headquartered in Accra, Ghana, and also has five Operating Units (OUs) in Cameroon, Ivory Coast, Namibia, Senegal and Zambia.
\end{abstract}

\title{
UNU-INRA Visiting Scholars Programme
}

The UNU-INRA Visiting Scholars Programme selects researchers on a competitive basis to spend three to four months undertaking research, analysing data and writing out the results of their work. The main outputs of the programme are Working Papers and Policy Briefs.

\section{About the Author}

Dr. Sowunmi is a Lecturer in the Department of Agricultural Economics, University of Ibadan, Nigeria. He holds PhD in Agricultural Economics from the University of Ibadan, Nigeria. His areas of Specialisation are Development Economics and Applied Spatial Econometrics. He has several international journal articles to his credit. He produced this paper, whiles serving as a Visiting Scholar at UNU-INRA. He can be contacted through the email: fasowunmi@live.co.uk

\section{Contact Details}

United Nations University Institute for Natural Resources in Africa (UNU-INRA)

2nd Floor, International House

University of Ghana Campus, Accra, Ghana

Private Mail Bag, KIA, Accra, Ghana

Email: inra@unu.edu

Tel: $\quad+233302213850$ Ext. 6318

Website: www.inra.unu.edu

(C) UNU-INRA, 2016

ISBN: 978-9988-633-08-0

Editorial and Layout: Praise Nutakor, UNU-INRA

Cover Photo:

Published by: UNU-INRA, Accra, Ghana

\section{Disclaimer:}

The views and opinions expressed in this publication are that of the author and do not necessarily reflect the official policy or position of the United Nations University Institute for Natural Resources in Africa (UNU-INRA). 


\begin{abstract}
Environmentally detrimental input (water turbidity) and the conventional production inputs are considered within the framework of stochastic frontier analysis to estimate environmental efficiencies of each fisherman in sand dredging and non-dredging areas. Cost and return analyses show the constituents of average gross profit of fishermen in the study area. The result revealed that environmental efficiency is low among fishermen in the sand dredging areas. Educational status, experience in fishing and sand dredging are the factors influencing environmental efficiency in the sand dredging areas. The gross profit per day is higher among the fishermen in the nondredging areas. The study affirmed large household size among fishermen. It was also revealed that fishermen in the fishing community around the dredging areas travel long distances in order to reduce the negative effect of sand dredging on their fishing activity. It is recommended that government regulate the activities of sand dredgers by restricting them to operate at nonfishing communities as well as intensifying family planning campaign in fishing communities to reduce the negative effect of high household size on fishing. The need to encourage fish rearing among fishermen to complement their meagre incomes is also imperative.
\end{abstract}

Keywords: Environmental efficiency, Detrimental input, Sand dredging, Stochastic frontier. 


\section{Abbreviations and Acronyms}

2SLS: $\quad$ Two-Stage Least Squares

ATA: $\quad$ Agricultural Transformation Agenda

DEA: Data Envelopment Analysis

EE: $\quad$ Environmental Efficiency

FAO: $\quad$ Food and Agricultural Organisation

FAS: $\quad$ Fish for All Submit

IDF: $\quad$ Input Distance Function

IFAD: International Fund for Agricultural Development

IV: $\quad$ Instrumental Variable

ML: $\quad$ Maximum Likelihood

NTU: $\quad$ Nephelometric Turbidity Units

OECD: $\quad$ Organisation of Economic Cooperation and Development

OLS: $\quad$ Ordinary Least Squares

SEM: $\quad$ Structural Equation Model

SFA: $\quad$ Stochastic Frontier Approach

SFLP: $\quad$ Sustainable Fisheries Livelihood Programme

TE: $\quad$ Technical Efficiency 


\section{Acknowledgements}

My profound gratitude goes to Dr. Elias T. Ayuk, Director of the United Nations University Institute for Natural Resources in Africa (UNU-INRA) for his hospitality and unflinching support during my visiting scholars programme. I express my deep gratitude to the Fellow in-charge of Green Economy: Dr. Calvin Atewamba for his professional contributions to the research. I also acknowledge other Fellows like Dr. E. Oku and Dr. Gessesse Dessie for their supports.

I am very grateful to Mr. Benjamin Turkson, Finance and Administrative Officer for his prompt responses to the Visiting Scholars' needs. Many thanks also go to Mrs. Eugina Aggrey, the Institute's Bilingual Secretary and Mrs Praise Nutakor, Communications and PR Associate for their supports. I equally appreciate supports received from Miss Fidelia Korley, Mr. Kwabena Asubonteng and Mr. William Briandt for their willingness to attend to my administrative needs at all times. My special thanks also go to other Visiting Scholars: Dr. Peter Oluwwafemi Agbola and Dr. Jonathan Hogarh for their friendliness and constructive criticism.

Additionally, I would like to express my special gratitude to Prof. M. A. Y. Rahji, the Head of the Department of Agricultural Economics, University of Ibadan, Nigeria for his unparalleled support. My thanks and appreciations also go to Dr. S. A. Yusuff, Dr. T. T. Awoyemi, Dr. Isacc Oluwatayo and Dr. Abimbola Adepoju for their supports.

Words cannot express my appreciation to my wife: Mrs Ololade Sowunmi and to my daughters: Moromoke and MoyosoreOluwa for their understanding and perseverance while the programme lasted. I am grateful to my students: Bello Abeeb Adetunji, Abayomi Hiqmat Durowoju and Olushola O. Oladipupo for their assistance in the collection and entering of the data used for this research. 


\section{Table of Contents}

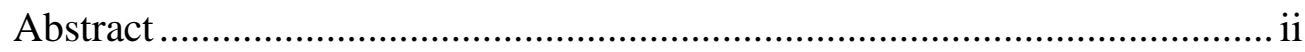

Abbreviations and Acronyms ...............................................................ii

Acknowledgements ................................................................................... iv

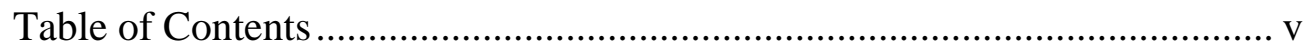

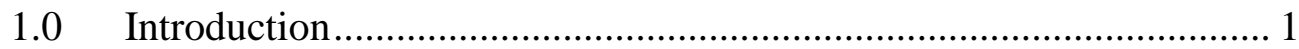

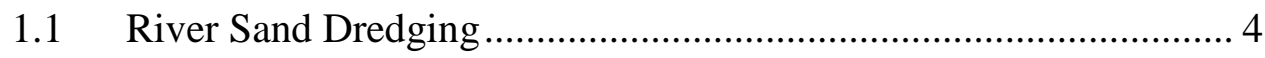

1.2 Statement of Problem ............................................................................. 8

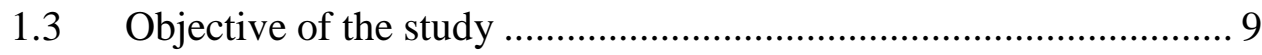

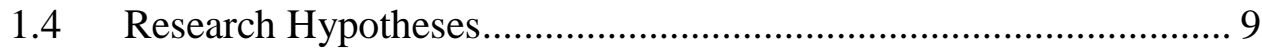

2.0 Theoretical Framework and Literature Review ............................... 10

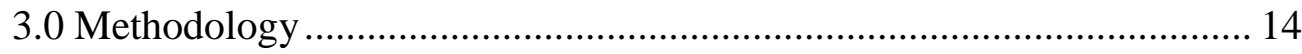

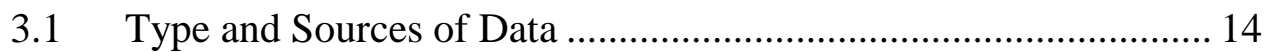

3.2 Analytical Framework for Environmental efficiency …................ 15

3.3 Empirical model for Environmental Efficiency ............................. 18

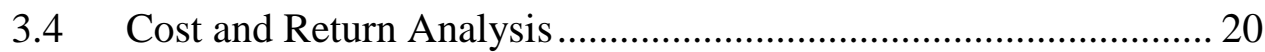

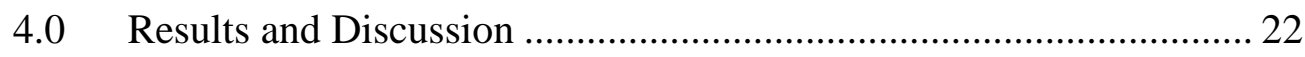

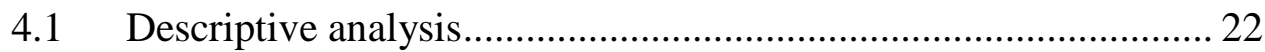

4.2 Determination of Environmental Efficiency (EE) from Stochastic

Frontier Approach (SFA) model ...................................................... 27

4.3 Determinants of Environmental Efficiency................................... 33

4.4 Breakdown of costs and returns of Fishermen in the study area.... 33

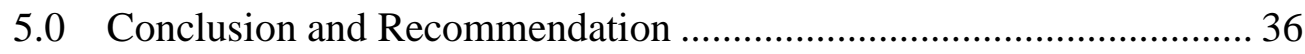

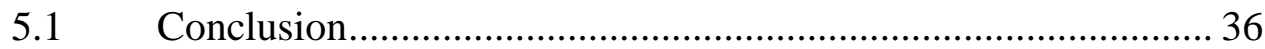

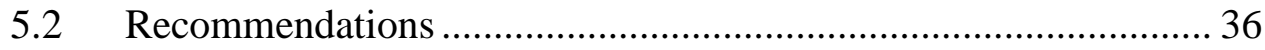

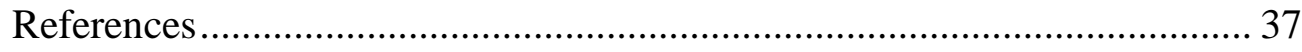

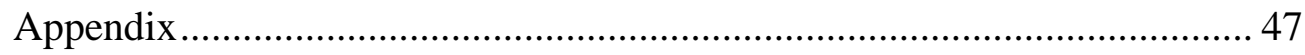




\section{List of Tables}

Table 1.0: Descriptive statistics by fishing site 23

Table 2.0: Distribution of sand dredging duration (year) ............................. 24

Table 3.0: Stochastic Production Frontier model ...................................... 28

Table 4.0: Descriptive statistics for the traditional and detrimental inputs .. 30

Table 5.0a: Descriptive statistics for Technical and Environmental

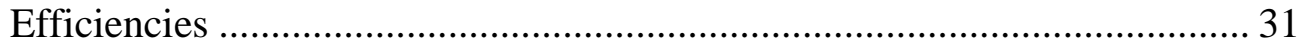

Table 6.0: Determinants of Environmental Efficiency ….............................. 33

Table 7.0: Breakdown of costs and return for fishermen............................... 34

\section{List of Figures}

Figure 1.0: A dredger in action at Epe, Lagos State ...................................... 4

Figure 2.0: A nearby dump site for dredged sand at Bayeku......................... 5

Figure 3.0: Sorting of fish at Elubo, Epe ................................................. 5

Figure 4.0: Typical fishing shed with dredging activity at the background at

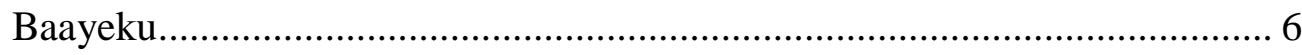

Figure 5.0: A high turbid water at one of the dredging sites. ....................... 7

Figure 6.0: Figure 6.0: Local sand miners at Majidun beach, Ikorodu.......... 7

Figure 7.0: Map of Ikorodu and Epe in Lagos state .................................... 14

Figure 8.0: Age distribution of respondents ............................................ 22

Figure 9.0a: A fisherman and his children looking disappointed at the sizes

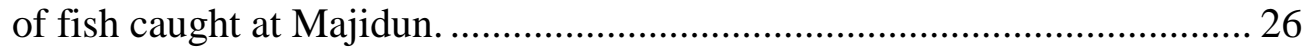

Figure 10.0: Distribution of Environmental Efficiency among Fishermen .. 32 


\subsection{Introduction}

Fishery is an important agricultural sub-sector in Nigeria. There are more than 6 million coastal and riverine artisanal fisher folks fishing the $46,300 \mathrm{~km}^{2}$ of maritime area and $125,470.82 \mathrm{~km}^{2}$ of inland water bodies in Nigeria (Fish for All Submit, 2005). Artisanal fishing is a subsistence fishing practice involving the use of simple tools such as throw nets and drag nets, rod and tackle as well as traditional fishing boats. The catch is only sufficient for the family meal and occasionally for sale (Wikipedia, 2014; Adesina and Ayanda, 2003). According to Bada (2005), artisanal fishing accounted for more than 80 per cent of total fish production in Nigeria. Apart from depending on fishing as their means of livelihood, 75 per cent of their households' animal protein intake comes from fishing.

Lagos state is one of the Nigerian coastline states dotted with many fishing communities. The coastline is about $180 \mathrm{~km}$ long and it is generally characterized by steep sandy beaches, offshore wave breakers and littoral drift. Some of important fishing communities in Lagos state are Badore, Agbowa, Ikosi and Oreta, Ibeshe, Ipakodo, Yovoyan, Moba, Majidun, Avijio and Itoikin. According to Sustainable Fisheries Livelihood Programme (2002), these fishing communities are characterized by high population densities which translate to higher pressure on the fisheries resources. Aside from high population density, other human activities such as sand dredging which has continue to spread in many fishing communities as a result of high demand for sand for construction purposes may also pose a difficult challenge to food security and employment opportunities in the fishing communities (SFLP, 2002). In this study, sustainability refers to agriculture's capacity to maintain its productivity while preserving the natural environment over the long run (Guo and Marchand, 2012).

The common fish species exploited through artisanal fishing units are: croakers (Pseudotolithus), threadfins (Galeoides, Pentanemus and Polydactylus), soles (Cynoglossidae), marine catfish (Arius), brackish water catfish (Chrisichthys), snapper (Lutjanus), grunters (Pomadasyidae), groupers (Epinephelus), and the estuarine white shrimp (Palaemon). Bonga dominates the pelagic fishery. However, there are modest catches of shad (Ilisha), sardine (Sardinella), various jacks (Caranx spp.) and Atlantic bumper (Chloroscombrus chrysurus) (FAO, 2008).

Sand dredging is an activity of harvesting the sand by excavation at least partly underwater (ask.com, 2014). Sand and gravel are essential materials for 
construction and high-quality material is often found in rivers and shallow seas (Whitehead, 2007; Kondolf, 1997; Meador and Layer, 1998). According to Kim et al. (2008), sand is a critical input for construction in industrial as well as developing nations. Combined with aggregate and cement, the resulting concrete is used for buildings, roads and pipes, among many other uses. Dredge, Drill \& Haul (2009) posited that Lagos may be the place with the highest sand need in Nigeria, if not in Africa, today; especially with the development of the World Bank-financed Lagos Mega City project, the Eko Atlantic City and innumerable residential and industrial estates, the proposed Eko Energy City, new roads, airports and seaports cropping up at the vast Lekki peninsula, in Badagry and practically every conceivable part of the Lagos metropolis and suburban areas. Hence, the pressure on fishing sites for sand.

Among the various yardsticks for determining the quality of river's water for most aquatic habitat to thrive (dissolved oxygen, $\mathrm{pH}$, water temperature, electrical conductivity, suspended solid among others), turbidity is a serious problem in sand dredging areas. Turbidity refers to an optical property of liquids that measures the scattering and/or absorption of light due to material suspended in solution. Suspended material includes inorganic and organic solids as well as living organisms. Suspended solids have complex optical and physical properties that often make them hard to quantify (Moore, 1977; Wilber, 1983; Sigler, 1990; Cone, 1995). High turbidity is treated as an environmentally detrimental input.

According to Dankwa et al. (2005), suspension of large quantities of solids in water column is one of the immediate physical effects resulting from sand dredging. Suspended solids may affect biological resources in various ways (Chansang, 1988), including physical harm to fish, interference with selfpurification of water by diminishing light penetration and, hence, photosynthesis reactions. This negatively affects phytophagous fishes by depriving them of algae, which serve as source of food. Sedimentation of soil particles may smother fish eggs and destroy communities of benthic organisms (Boyd, 1984).

U.S. Army Corps of Engineers (2004) and Anchor Environmental (2003) submitted that the resultant turbidity from sand dredging reduces visibility, causing difficulty for fish and other aquatic habitat in locating prey. Other effects of turbidity include disruptions to food web dynamics through decreased predator feeding success and enhanced prey survival (Vinyard and O'Brien, 1976). Effects on fish behaviour are not uncommon with disruption of migration and spawning reported (Cone, 1995). Sublethal and lethal effects 
of turbidity have been noted for a number of organisms and include decreased disease resistance, hatching success, growth and egg development, as well as suffocation and death due to enhanced predation success (Moore 1977, Simenstad 1990, Cone 1995).

According to Balogun (2011), River sand though is vital for human use; the manner of mining has presented a multifaceted problem. Permit for dredging, preserving the environment, meeting the demand of sand for construction, as well as putting food on the table of the local fishermen are some of the nagging questions waiting to be addressed.

Past efforts (Mafimisebi et al., 2013; Idowu, 2010; Ekeke et al., 2008; Tae et al., 2008; Anyanwu et al., 2009; Ogunniyi et al., 2012; Sesabo and Tol, 2007) failed to account for the effect of water quality as environmental factors on artisanal fishing. Lack of data on environmental factors may be attributed for this. According to Organisation of Economic Cooperation and Development report (1997), the supply of quantitative information about agroenvironmental linkages is inadequate. Without such information, governments and other users cannot adequately identify, prioritise and measure the environmental impacts associated with agriculture, which makes it difficult to improve the targeting of agricultural and environmental programmes and to monitor and assess policies.

Currently, world order advocates for environmentally efficient economy that brings about sustainability of natural resources. The role of artisanal fishing as a means of livelihood and source of animal protein cannot be overemphasised. With the increasing consciousness about the environmental problems caused by sand dredging, the environmental performance of artisanal fishing has become increasingly important. With the increasing interest in environmental sustainability, another aspect of efficiency, which is environmental efficiency, has emerged. Environmental efficiency is defined as the ratio of minimum feasible to observe use of an environmentally detrimental input, conditional on observed levels of the desirable output and the conventional inputs (Reinhard, 1999).

While there are substantial literatures (Mafimisebi et al., 2013; Idowu, 2010; Ekeke et al., 2008; Tae et al., 2008; Anyanwu et al., 2009; Ogunniyi et al., 2012; Sesabo and Tol, 2007) on the economy of artisanal fishing (production, efficiency, cost and return), biological and chemical effects of sand dredging on aquatic habitat (Igben, 2014; Muhammad et al., 2011; Fischer and Paukert, 2009; Collins, 1995; Burcynski, 1991; Hay and McKinnell, 2002; Anchor Environmental 2003); the same cannot be said on the effect of sand dredging 
on the economy of artisanal fishing as well as how this important agricultural sub-sector has been fairing in terms of input utilization, bearing in mind the impact of environmentally detrimental input like turbidity. The study is set out to fill this gap in literature and also to identify the variations inputs associated with this environmental factor. Generally, this study contributes positively to the on-going environmental sustainability of natural resources endowment in Africa.

\subsection{River Sand Dredging}

River sand Dredging is an excavation activity or operation usually carried out at least partly underwater in shallow seas or fresh water with the purpose of gathering up bottom sediments and disposing of them at different locations (US Environmental Protection Agency, 1995; Wikipedia, 2014). Dredger is any device, machine, or vessel that is used to excavate and remove material from the bottom of a body of water (Branz von Mayer, 2011). The process of dredging creates spoils (excess material), which are carried away from the dredged area. Dredging can produce material for land reclamation or other purposes (usually construction-related), and has also historically played a significant role in gold mining (Wikipedia, 2014).

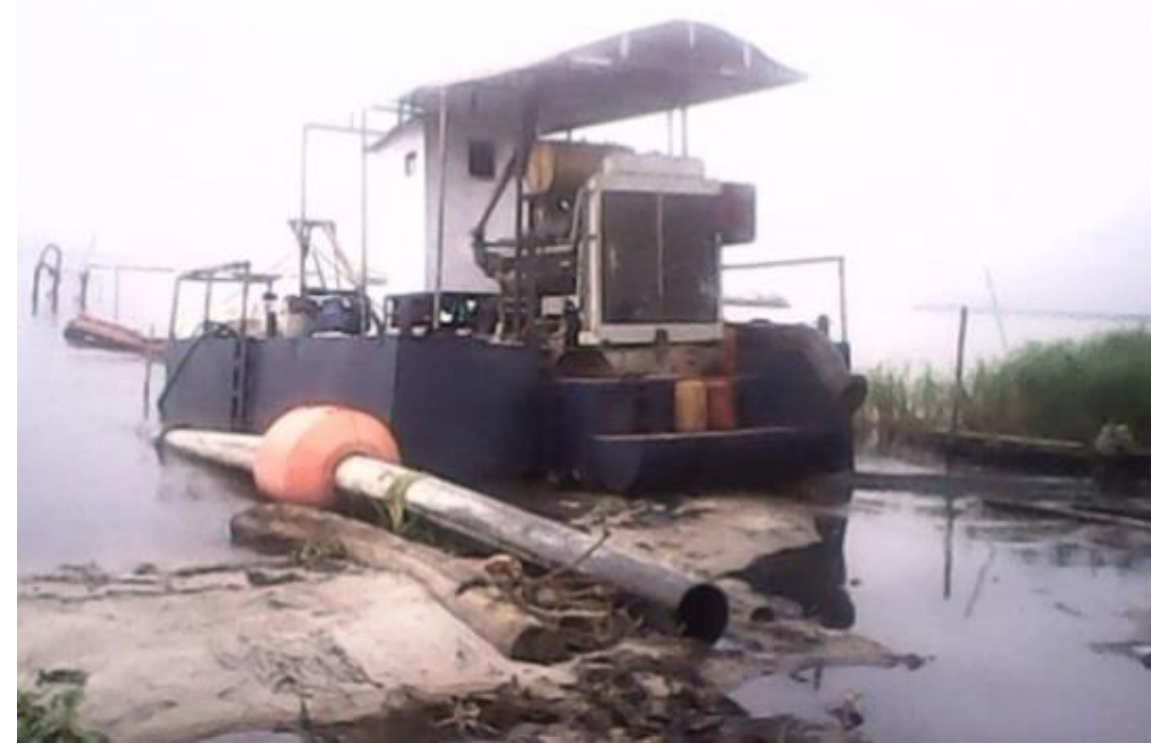

Figure 1.0: A dredger in action at Epe, Lagos State 


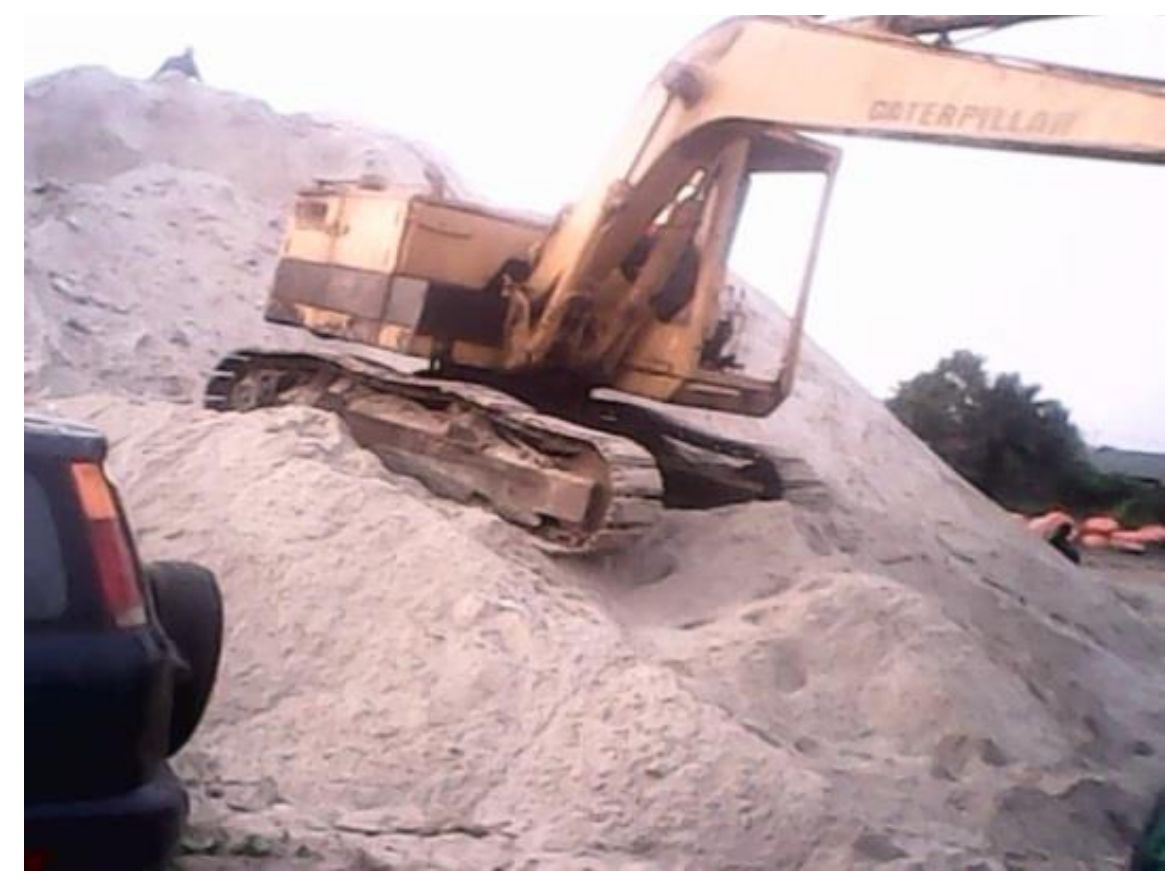

Figure 2.0: A nearby dump site for dredged sand at Bayeku

Effects of sand dredging on aquatic habitat include habitat removal, removal of existing benthic populations, burial of nearby benthos due to turbidity or side casting activities, increased turbidity, and alterations to current patterns, sediment, water quality, salinity and tidal flushing. Direct dredging effects to fish may include capture and killing by dredge equipment, disruption of normal foraging or spawning behaviours, and gill injury from exposure to local increases in turbidity (River and Coast, 2010).

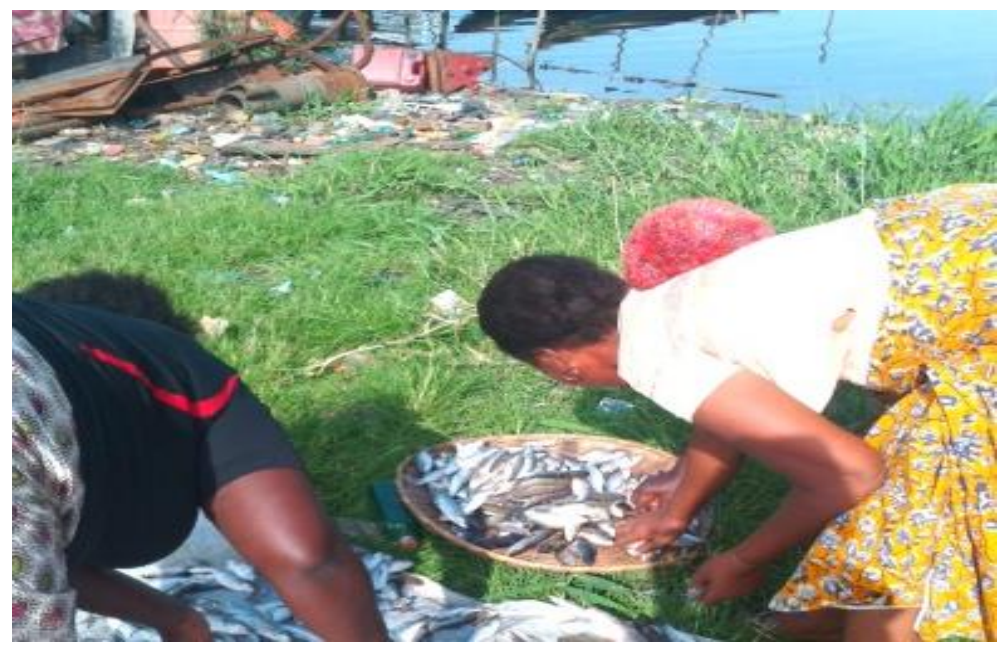

Figure 3.0: Sorting of fish at Elubo, Epe 


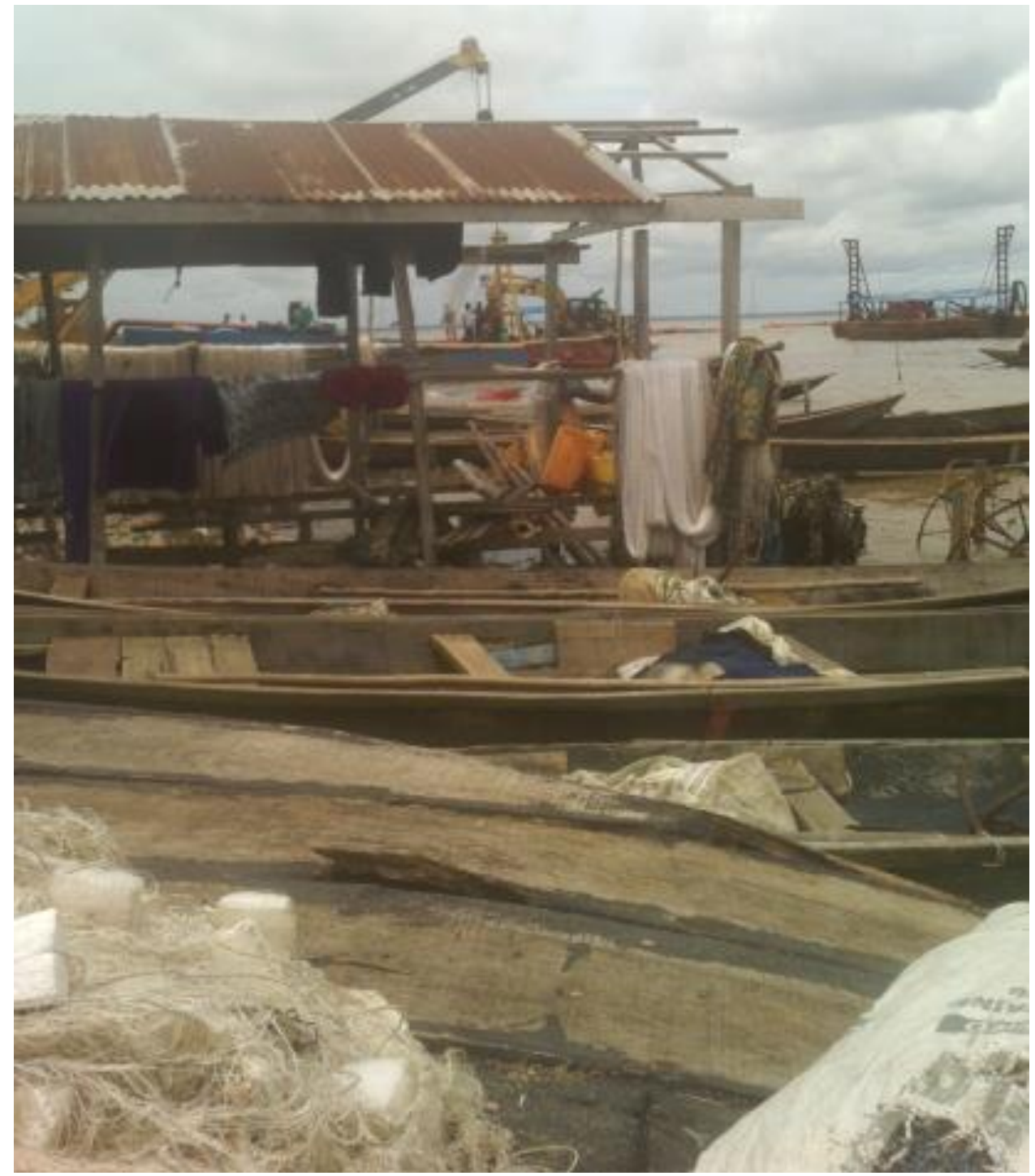

Figure 4.0: Typical fishing shed with dredging activity at the background at Baayeku

Based on the basic means of moving material, USEPA and USACE (1992) classified sand dredging into two, namely, hydraulic and mechanical dredging. Hydraulic dredges remove and transport sediment in liquid slurry form. They are usually barge mounted and carry diesel or electric-powered centrifugal pumps with discharge pipes ranging from 6 to 48 inches in diameter. The pump produces a vacuum on its intake side, and atmospheric pressure forces water and sediments through the suction pipe. The slurry is transported by pipeline to a disposal area. 


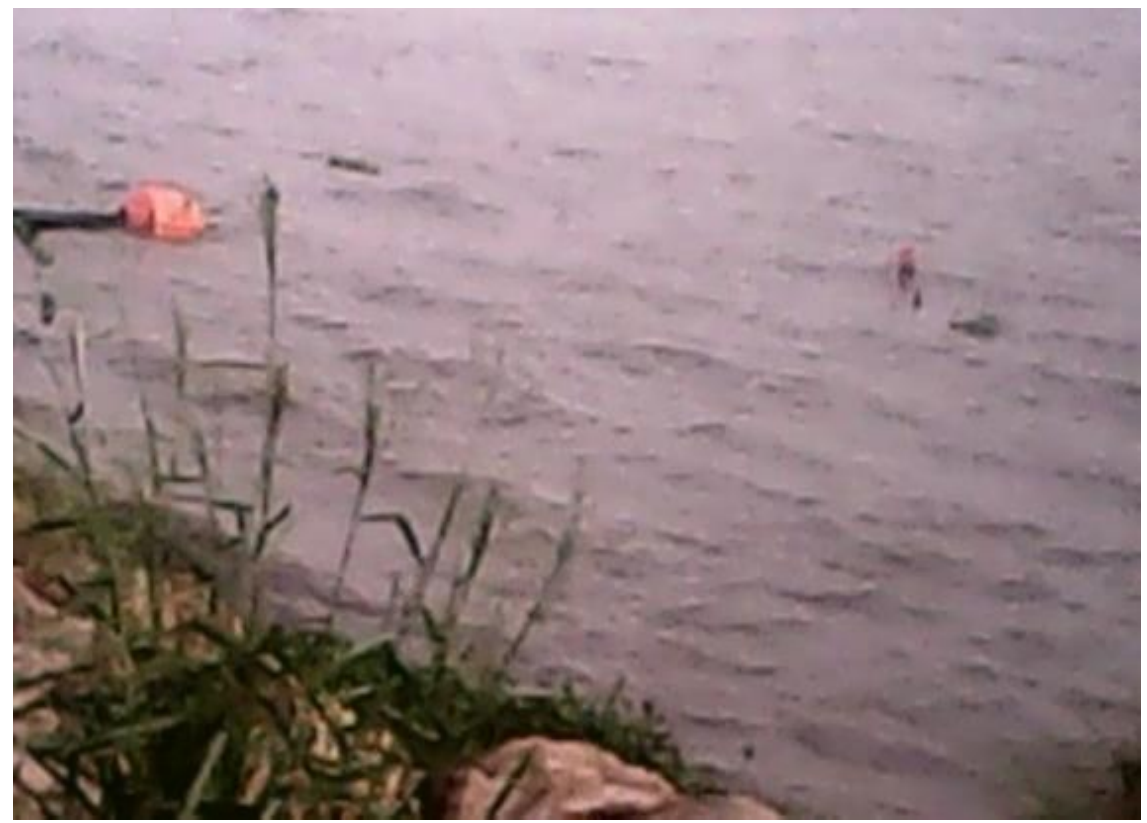

Figure 5.0: A high turbid water at one of the dredging sites.

(Source: Author's picture)

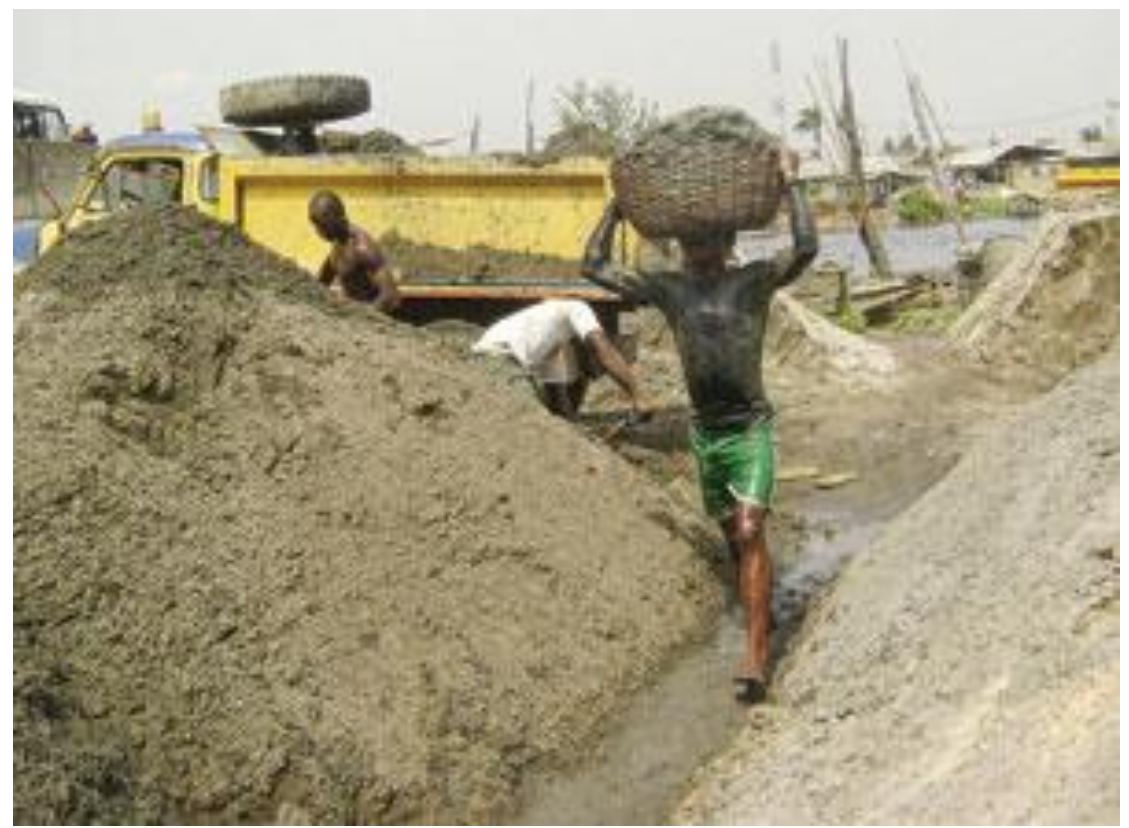

Figure 6.0: Figure 6.0: Local sand miners at Majidun beach, Ikorodu

Source: http://www.vanguardngr.com/2011/04/ 
Mechanical dredges remove bottom sediments through the direct application of mechanical force to dislodge and excavate the material at almost in situ densities. Backhoe, bucket ladder, bucket wheel, and dipper dredges are types of mechanical dredges. Sediments excavated with a mechanical dredge are generally placed into a barge or scow for transportation to the disposal site. Hydraulic dredging is the most common among the large scale sand dredging firms while there are small scale sand dredgers that make use of locally made boats and basket in the study area.

\subsection{Statement of Problem}

Dredging activities is one of the ways through which aquatic habitat is disturbed. Rivers and Coast (2010) stated that the economic consequences of sand dredging may include declines in fishery species populations and catch, impacts of increased turbidity or toxin release on aquaculture activities and increased shoreline erosion due to boat wakes in previously non-boatable areas.

Increasing demand for sand for construction purpose and the supply gap created by dredging on land has made river/sea sand dredging a major threat to aquatic habitat. According to Ramilan et al. (2011), until recently, analysis of the performance of the agricultural sub-sector has tended to ignore such negative externalities. The current emphasis on environmental issue makes it pertinent for farmers to target improvements in both environmental performance and productivity. They submitted that measuring the environmental performance of farms and integrating this information into farm productivity calculations should assist in making informed policy decisions which promote sustainable development.

While there are studies on effect of sand dredging on artisanal fishing in Nigeria, none of these studies incorporate environmental factor in their analyses. Reinhard et al. (1999) identifies dairy farms which were both technically and environmentally efficient by treating nitrogen surplus as an environmentally detrimental input. This study utilised this approach in artisanal fishing by considering turbidity in sand dredging and non-dredging sites as an environmentally detrimental input. The study provides answers to the following research questions: Does environmental factor (water turbidity) significantly influence the quantity of fish caught per day in the study area? What are the environmental efficiencies of artisanal fishermen in sand dredging and non-dredging sites? Does sand dredging significantly affect environmental efficiency of fishermen in the study area? What are the factors influencing environmental efficiencies in the study area? Is there significant 
variation in the quantity of fish caught per day by fishermen in the sand dredging and non-dredging areas?

\subsection{Objective of the study}

The broad objective of the study is to examine the environmental and economic burden of sand dredging on artisanal fishing in Lagos state, Nigeria. The specific objectives are to:

(i) analyse whether there are variations in output and kilometres covered (fish caught) among the artisanal fishermen in sand dredging and non-dredging sites in the study area;

(ii) determine the environmental efficiencies of artisanal fishing in sand dredging and non- dredging sites;

(iii) determine the factors influencing environmental efficiency in the study area;

(iv) determine the costs and returns of fishermen in non-dredging and dredging areas.

\subsection{Research Hypotheses}

(i) $\mathrm{H}_{\mathrm{o}}$ : There is no significant difference in the quantity of fish caught per day between fishermen in sand dredging and non-dredging sites.

(ii) $\mathrm{H}_{\mathrm{o}}$ : There is no significant difference in the environmental efficiencies of the fishermen in non-dredging and dredging areas.

(iii) $\mathrm{H}_{\mathrm{o}}$ : Environmental efficiency is not influenced by sand dredging. 


\subsection{Theoretical Framework and Literature Review}

The study is based on the economic theories of a common-property resource and production efficiency. Economic Theory of Common-Property Resource states that the ownership of resource is based on descent rights and age-long socio-cultural values which confer equal rights on the member. The owners demonstrate strict compliance with the inheritance rules and practices, maintain exclusive rights over the resources and uphold the principle of inalienability so as to ensure ease of transferability to their heirs (Olomola, 1998).

Common-property natural resources are free goods for the individuals in the community and scarce goods for society. Under unregulated private exploitation, they can yield no rent; that can be accomplished only by methods which make them private property or public (government) property, in either case subject to a unified directing power (Gordon, 1954; Olomola, 1993). Regardless of who is governing a common-property resource, it is subject to basic concepts of production theory. Apart from being subject to law of diminishing returns, other human activities such as, over-exploitation, sand dredging may hasten the rate in which fish production reaches third stage of production (fish output decreasing at decreasing rate).

The conventional definition of efficiency can be traced to the work of Farrell (1957) where the efficiency of a farm is measured directly from observed data. It refers to "how well" or "how effective" a decision making unit combines inputs to produce an output. Efficiency consisted of both technical and allocative efficiencies. Technical efficiency focuses on output produced from a given bundle of inputs and technology, while allocative efficiency focuses on the ability and willingness of an economic unit to minimise costs of production for a given set of input prices through substitution or reallocation of inputs (Graham, 2004). More recently, a third type of efficiency, which is environmental efficiency, is being defined and measured as a result of the impact agriculture has on the environment. Environmental efficiency is the ratio of minimum feasible to the observed use of an environmental detrimental input (Reinhard et al.1999).

There are divergent findings on the effect of sand dredging on the distribution of fish. Tillin, et al. (2011) and Mmom and Chukwu-Okeah (2012) identified fish, seabed habitats and benthic organisms, marine mammals; and seabirds as the main groups of aquatic organisms that could be affected by sand dredging. Specifically, they affirmed that sand dredging leads to loss of spawning ground and nursery areas by fish. Yen and Rohasliney (2013) study on status 
of water quality subject to sand mining in the Kelantan River, revealed that total suspended solids and turbidity exceed the Malaysian Interim National Water Quality Standard (INWQS) range. They submitted that the extremely high content of TSS and the turbidity have caused poor and stressful conditions for the aquatic life in the Kelantan River. Also, in a study on impact of mining operations on the ecology of river Offin, Dankwa et al. (2005) posited that higher diversities of phytoplankton were recorded at sites where turbidity was high. Autrophs (blue-green and green algae) were virtually absent from sites with high turbidity. Forsage and Carter (1973); Brown, et al. (1998) and Levine Fricke (2004) were not categorical on their findings while Frid and Clark, 2000; Greenstreet and Hall, (1996) revealed that larger bodies of organisms (fish and benthos) were more prevalent before intensive sand dredging. In a study by Ekeke et al. (2008) on sand dredging impact on fish catch in Bonny river estuary, they revealed that sand dredging had no significant impact on the fish caught.

Faced with different challenges, sustainability is achieved through efficient utilization of the available resources (production inputs and environmental factor). Several studies (Ogunniyi et al., 2012; Kareem et al., 2012; Pascoe and Tingley, 2005; Oliviera et al., 2010; Sesabo and Tol, 2005; Alam, 2011; Squires et al., 2003; Okoruwa and Ogundele, 2006; Khumbhakar and Heshmatic, 1995; Tingley et al., 2005; Conglan, 1998; Okoruwa et al., 2014) have been carried out on the efficiency (technical) of artisanal fishing and other agricultural subsectors. Most of these studies used stochastic frontier method ranging from double-log to transcendental logarithm (translog) function. The major shortcoming of these studies is that environmental factor was not incorporated into the model. Policy decisions emanating from these studies may not promote sustainable development.

Van Meensel et al. (2010), conventional frontier approaches are environmentally adjusted through incorporating the materials balance principle. As environmental issues are becoming a major matter of concern in resource management, there has been a growing literature devoted to incorporating environmental issues into traditional neoclassical production theory. Although there is dearth of study on the incorporation of environmental factor in fishery subsector, the same cannot be said in other agricultural subsector. There are two strands of studies that have attempted to incorporate environmental effects into the output vector. In the first strand, the general strategy is to include environmental effects in the output vector, and then to obtain inclusive measures of technical efficiency, and occasional productivity change, which incorporate the generation of one or more environmental effects as by-products of the production process. In doing so, 
environmental effects are treated as an additional undesirable output which is costly to dispose (see Pittman, 1983; Fare et al., 1989; Fare et al., 1993). In the second strand model, the environmental effect is regarded as a conventional input rather than as an undesirable output (see Pittman, 1981 and Reinhard et al., 1999). This is the model (second strand) used in this study.

In a study on technical and environmental efficiencies and best management practices in agriculture, Tamini et al. (2011), data were collected on three environmental variables based on their emission levels (kilograms). The environmentally detrimental variables are nitrogen, phosphorus and sediments. However, because of the high correlation coefficients between these variables, only phosphorus was considered in their analysis. Using Input Distance Function (IDF) to estimate the technical and environmental efficiencies of 210 farms located in the Chaudie're watershed (Quebec), the results showed that there is a significant correlation between the two efficiencies. The principal advantage of the distance function representation is that it allows for the possibility to specify a multiple input, multiple-output technology when price information is not available or, alternatively, when price information is available but cost, profit or revenue representations are precluded because of violations of the required behavioural assumptions (Färe and Primont, 1995).

In another study on econometric analysis of economic and environmental efficiency of Dutch dairy farms by Reinhard et al. (1999 and 2000), nitrogen surplus was modelled as an environmentally detrimental input along with production input in stochastic frontier used. Using stochastic frontier approach, the result shows that the mean environmental efficiency score of the dairy farms in the panel is 0.44 . According to this model the discharge of nitrogen can be reduced with $56 \%$ without a loss in production. Also, the result showed that environmental efficiency can be improved, for instance by encouraging a higher milk yield (stimulating genetics research) or by providing the farmer with more insight into the nutrient balance of his farm. The advantage of Stochastic Frontier Approach is that it distinguishes effects of noise from the effects of inefficiency unlike DEA that lumps the effects of noise and inefficiency together. Also, the necessary assumptions with respect to the environmentally detrimental variables can be tested using SFA. It is however prone to specification error unlike Data Envelopment Analysis (DEA).

Furthermore, Guo and Marchand (2012) and Marchard and Guo (2014) considered pure nitrogen as environment detrimental variable in a study on the environmental efficiency of organic farming in developing countries: a case 
study from China. They reasoned that pure nitrogen is the most important nutrient input for paddy rice production as well as being the biggest pollutant of underground water and air resulting from agricultural production in China. The empirical results using translog production function demonstrate that organic farming could lose its advantage of environmental efficiency in the process of scaling up due to the overuse of nitrogen. They suggest that to maintain the sustainability of organic farming in developing countries, development agencies should replace organic fertilizer subsidies by more technical support, slow down the expansion of organic farming and make strong efforts to control the use of external nutrients. Van Meensel et al. (2010) carried out a study, comparing frontier methods for economic-environmental trade-off analysis using pig finishing activity. The study focussed on nitrogen pollution as an environmental variable. Based on the material balance principle, nitrogen excretion from pig finishing is calculated as the amount of nitrogen entering the pig finishing activity as inputs minus the activity under the form of useful output. Conventional frontier methods show that a pure technical efficiency increase improves both absolute economic and absolute environmental performance (positive trade-off).

However, this study considered turbidity as the environmentally detrimental variable. Among all the indicators of water quality, turbidity is used because it is a major problem in sand dredging area. Most aquatic animals are sensitive to change in water turbidity. Also, stochastic frontier approach is adopted because necessary assumptions on the environmental detrimental variable can be tested among other advantages. 


\subsection{Methodology}

This section discusses the source of data, the methods used in the analysis of data collected from the study area. The first part contains the analytical framework on the concepts of technical and environmental efficiency. The second part contains the model specifications for technical and environmental efficiencies. The third part contains how the study arrived at the various cost items as well as the revenue accruable to the fishermen in the study area.

\subsection{Type and Sources of Data}

The study utilized primary and secondary data. The primary data were collected in July 2014 from two Local Government Areas (LGA) in Lagos State known for artisanal fishing and sand dredging; namely Ikorodu and Epe. The two local government areas have rivers that empty into Lagos lagoon. The map of the two contiguous LGAs is shown in figure 7.0 below:

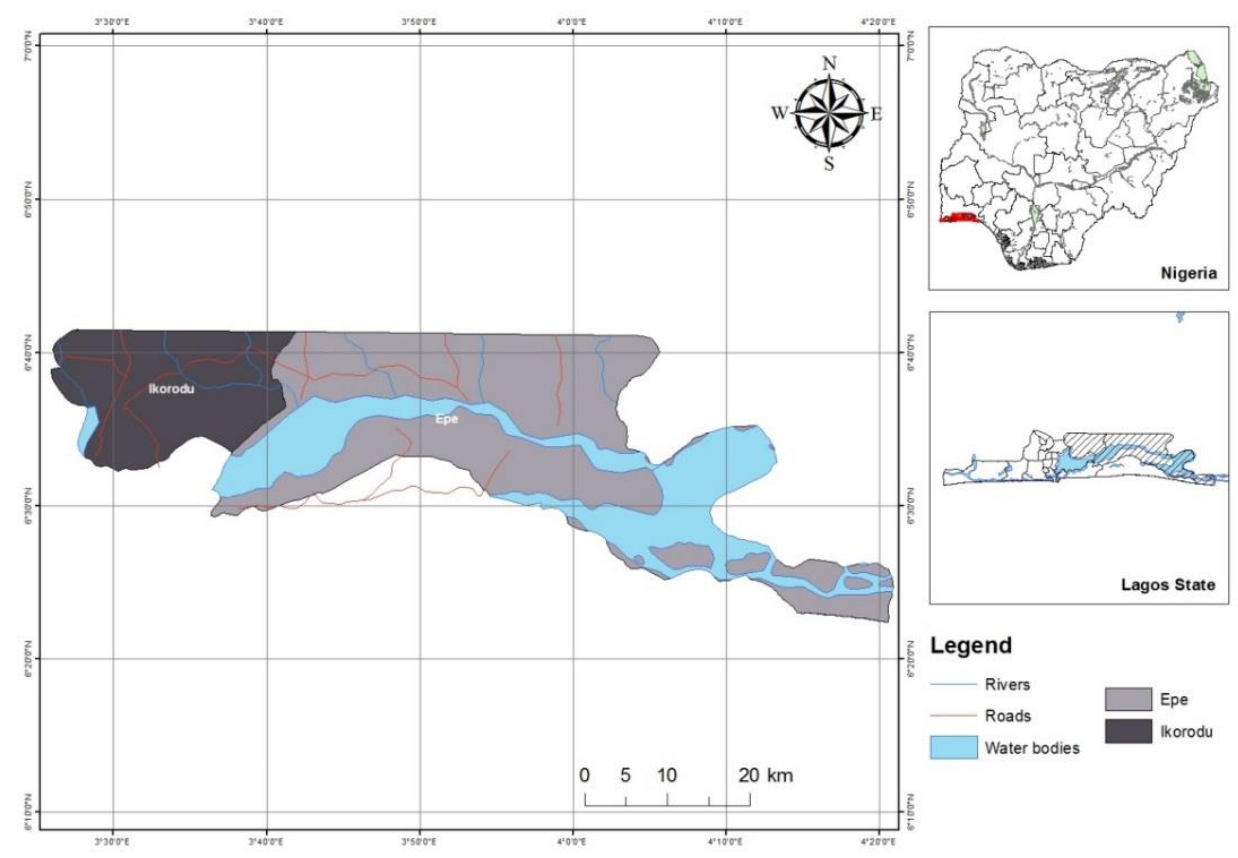

Figure 7.0: Map of Ikorodu and Epe in Lagos state

\section{Source: UNU-INRA's GIS Unit}

The primary data were collected using two-stage sampling technique (purposive and simple random). The fishing communities sampled in the two LGAs are Oreta, Majidun, Itoikin, Ofin, Bayeku, Ijede, Ejinrin, Elubo and Iponmi via Agura Gberigbe. A total of 450 questionnaires that addressed the objective of the study were administered while 332 were returned (see the 
appendice for the detail of how I arrived at the sample size of 450). After processing, 314 of the questionnaires are appropriate for the analysis.

Data collected from fishermen in sand dredging and non-dredging sites include socio-economic characteristics, the average quantity of fish caught per day $(\mathrm{kg})$, price per kilogramme of fish, average hours spent per fishing trip as well as the kilometres covered. Other data collected are the various cost items used for fishing (boat, net, rope, basket, paddle, and other locally made traps used). Being cross-sectional data, it is possible to estimate the performance of each fisherman at a specific period in time, unlike panel data that estimate the time pattern of performance (Kumbhakar and Lovell, 2000).

Secondary data on the water quality of the fishing communities sampled were sourced from Odunaike et al. (2013), Nkwoji et al. (2010) and Idowu et al. (2014)

\subsection{Analytical Framework for Environmental efficiency}

The Environmental Efficiency (EE) that this study estimates is different from the conventional Technical Efficiency (TE). Environmental efficiency is defined as the ratio of minimum feasible to observed use of an environmentally unfavourable input (water turbidity), based on observed levels of output and the traditional production inputs. The EE is calculated from TE with the classical approach of Stochastic Frontier Approach (SFA). Determination of EE follows Reinhard et al. (1999) two-step approach. EE is first calculated from TE using SFA. This is followed by regressing EE on variables that are not used in the estimation of TE. Following Reinhard et al. (2000), the non-radial environmental efficiency can formally be defined as:

$$
E E_{i}(x, y)=\left[\min \theta: F\left(X_{i}, \theta Z_{i}\right) \geq y_{i}\right] .
$$

Where $y_{i}$ is the quantity of fish caught per day, using $X_{i}$ of the conventional inputs and $Z_{i}$ - the environmentally detrimental input. $F($.) is the best practise frontier with $X$ and $Z$.

Technical efficiency is measured using an output-expanding orientation, as the ratio of observed to maximum feasible output, conditional on technology and observed input usage. This is defined as:

$$
T E=\left[\max \{\phi: \phi Y \leq F(X, Z\}]^{-1}\right.
$$


In SFA (Aigner et al., 1977, Meeusen and van den Broeck, 1977) inefficiency is modelled by an additional error term with a two-parameter (truncated normal) distribution introduced by Stevenson (1980). A stochastic production frontier is defined by:

$$
Y_{i t}=f\left(X_{i t}, Z_{i t}, \beta, \gamma, \zeta\right) \exp \varepsilon_{i t}
$$

Where all fishermen are indexed with a subscript $i$ and period of data collection indexed with a subscript $t ; Y_{i t}$ denotes the quantity of fish caught per day; $X_{i t}$ is a vector of normal inputs (with $X_{i t l}$ is the labour hour, $X_{i t 2}$ the capital, $X_{\mathrm{it} 3}$ the variable input (bait), $Z_{i t}$ is a vector of environmentally detrimental input (with $Z_{i t 1}$ is the water turbidity), $\beta, \gamma$, and $\zeta$ are parameters to be estimated; $V_{i t}$ is a symmetric random error term, independently and identically distributed as $N\left(0, \sigma_{v}^{2}\right)$, intended to capture the influence of exogenous events beyond the control of fishermen; $\varepsilon_{i t}$ is a composite error term, $U_{i}$, is a nonnegative random error term, independently and identically distributed as $N^{+}\left(\mu, \sigma_{u}^{2}\right)$.

$$
\varepsilon_{i t}=V_{i t}-U_{i}
$$

The stochastic version of the output-oriented technical efficiency measure (2) is given by the expression:

$$
T E_{i t}=\frac{Y_{i t}}{Y_{i t}=f\left(X_{i t}, Z_{i t}, \beta, \gamma, \zeta\right) \exp \left(V_{i t}\right)}=\exp (-U i) \ldots \ldots . .(4)
$$

Since $U_{i} \geq 0,0 \leq \exp \left(U_{i}\right) \leq 1$. In order to implement (4), technical inefficiency must be separated from statistical noise in the composed error term $\left(V_{i t}-U_{i}\right)$. Battese and Coelli $(1988,1992)$ have proposed the technical efficiency estimator as:

$$
T E_{i t}=E\left[\exp \left\{-U_{i}\right\}\left(V_{i t}-U_{i}\right)\right]
$$


Within the framework developed by Reinhard et al. (1999), TE is calculated using a standard translog production function as shown in equation (6) (Christensen et al. 1971) ${ }^{1}$.

One of the main advantages of translog production function is that, unlike in the case of Cobb-Douglas production function, it does not assume rigid premises such as: perfect or "smooth" substitution between production factors or perfect competition on the production factors market (Klacek, et al., 2007). Translog production function can be used for the second order approximation of a linear-homogenous production, the estimation of the Allen elasticities of substitution, the estimation of the production frontier or the measurement of the total factor productivity dynamics (Pavelescu, 2011).

$$
\begin{array}{r}
\ln \left(Y_{i, t}\right)=\beta_{0}+\sum_{j=1}^{m} \beta_{j} \ln \left(X_{i, j, t}\right)+\beta_{z} \ln \left(Z_{i, t}\right)+\frac{1}{2} \sum_{j=1}^{m} \sum_{k=1}^{m} \beta_{j k} \ln \left(X_{j i, t}\right) \ln \left(X_{k i, t}\right) \\
+\frac{1}{2} \sum_{j=1}^{m} \beta_{j z} \ln \left(X_{j i, t}\right) \ln \left(Z_{i, t}\right)+\frac{1}{2} \beta_{z z} \ln \left(Z_{i, t}\right)^{2}-U_{i, t}+V_{i, t}
\end{array}
$$

where $\mathrm{i}=1, \ldots ., \mathrm{n}$ are total sampled fishermen and $\mathrm{t}=1, \ldots ., T$ are the number of periods; $j, k=1,2, \ldots . ., \mathrm{m}$ are the applied traditional inputs; $\ln \left(Y_{i, t}\right)$ is the logarithm of the quantity of the fish caught by fisherman $i$; $\ln \left(X_{i j, t}\right)$ is the logarithm of the $j^{\text {th }}$ traditional input applied by the $i^{\text {th }}$ individual fisherman; $\ln \left(Z_{i, t}\right)$ is the logarithm of the environmental detrimental input applied by the $i^{\text {th }}$ individual; and $\beta_{j}, \beta_{z}, \beta_{j k}, \beta_{j z}$ and $\beta_{\mathrm{zz}}$ are parameters to be estimated ${ }^{2}$. The logarithm of the output of a technically efficient fisherman $Y_{i, t}^{F}$ with $X_{i, t}$ and $Z_{i, t}$ can be obtained by setting $U_{i, t}=0$ in Equation 6. However, the logarithm of the output of an environmentally efficient fisherman $Y_{i, t}$ with $X_{i, t}$ and $Z_{i, t}$ is obtained by replacing $Z_{i, t}$ by $Z_{i, t}^{F}$ where $Z_{i, t}^{F}=E E_{i, t} * Z i, t$, and setting $U_{i, t}=0$ in Equation 6 as follows:

$$
\begin{aligned}
\ln \left(Y_{i, t}\right)=\beta_{0}+\sum_{j=1}^{m} \beta_{j} \ln \left(X_{i, j, t}\right)+\beta_{z} \ln \left(Z_{i, t}\right)+\frac{1}{2} \sum_{j=1}^{m} \sum_{k=1}^{m} \beta_{j k} \ln \left(X_{j i, t}\right) \ln \left(X_{k i, t}\right) \\
+\frac{1}{2} \sum_{j=1}^{m} \beta_{j z} \ln \left(X_{j i, t}\right) \ln \left(Z_{i, t}\right)+\frac{1}{2} \beta_{z z} \ln \left(Z_{i, t}\right)^{2}+V_{i, t}
\end{aligned}
$$

\footnotetext{
${ }^{1}$ The negative sign is used in order to show that the term $-U_{i, t}$ represents the difference between the most efficient fisherman (on the frontier) and the sampled fishermen.

${ }^{2}$ Similarity conditions are imposed, that is, $\beta_{j k}=\beta_{k j}$.
} 
The logarithm of $E E\left(\ln E E_{i, t}=\ln Z_{i, t}\right)$ can now be calculated by setting equations6 and 7 equal as follows:

$$
\frac{1}{2} \beta_{z z}\left(\ln E E_{i, t}\right)^{2}+\left(\ln E E_{i, t}\right)\left[\beta_{z}+\sum_{j=1}^{m} \beta_{j z} \ln X_{i j, t}+\beta_{z z} \ln Z_{i, t}\right]+U_{i, t}=0
$$

By solving Equation $8, \ln E E_{i, t}$ is obtained as shown below:

$$
\begin{aligned}
\ln E E_{i, t}= & =(\overbrace{\beta_{z}+\sum_{j=1}^{m} \beta_{j z} \ln X_{i j, t}+\beta_{z z} \ln Z_{i, t}}^{A}) \\
& \left. \pm\left\{(\overbrace{\beta_{z}+\sum_{j=1}^{m} \beta_{j z} \ln X_{i j, t}+\beta_{z z} \ln Z_{i, t}}^{B})-2 \beta_{z z} U_{i, t}\right\}^{0.5}\right] / \beta_{z z}
\end{aligned}
$$

As mentioned by Reinhard et al. (1999), the output-oriented efficiency is estimated econometrically whereas environmental efficiency (Equation 8) is calculated from parameter estimates $\left(\beta z\right.$ and $\left.\beta_{z z}\right)$ and the estimated error component $\left(U_{i, t}\right)$. Since a technically efficient fisherman $\left(U_{i, t}=0\right)$ is necessarily environmentally efficient $\left(\ln E E_{i, t}=0\right)$. The $\operatorname{sign}+\sqrt{ }$ is ideal. $^{3}$

\subsection{Empirical model for Environmental Efficiency}

In the case of artisanal fishing, three traditional inputs (labour hour, depreciation value on fixed items used in production and bait used for setting trap for fish) and one environmental detrimental input (water turbidity) are identified for the production function.

\footnotetext{
${ }^{3}$ The sign in front of the term B should be positive. Thus, if $U_{i, t}=0$, then $\ln E E_{i t}=0$,
} 


$$
\begin{aligned}
& \text { Quantity }_{k, i, t}=\beta_{0}+\beta_{1} \text {. Labour hour }{ }_{k, i, t}+\beta_{2} \text {. } \text { Capital }_{k, i, t}+\beta_{3} . \text { Bait }_{k, i, t} \\
& +\beta_{4} . \text { Water Turbidity }_{k, i, t}+\beta_{5} . \text { Labour hour }_{k, i, t}^{2}+\beta_{6} . \text {. }_{\text {apital }}^{2}, i, t \\
& +\beta_{7} . \text { Bait }_{k, i, t}^{2}+\beta_{8} . \text { Water Turbidity }{ }_{k, i, t}^{2}+\beta_{9} \text {.Labour hour }{ }_{k, i, t} . \text { Capital }_{k, i, t} \\
& +\beta_{10} \text {.Labour hour }{ }_{k, i, t} \text {. } \text { Bait }_{k, i, t}+\beta_{11} \text {. Labour hour }{ }_{k, i, t} \text {.Water Turbidity }{ }_{k, i, t} \\
& +\beta_{12} \text { Capital }_{k, i, t} \text {. } \text { Bait }_{k, i, t}+\beta_{13} \text {. } \text { Capital }_{k, i, t} \text {. Water Turbidity }{ }_{k, i, t} \\
& +\beta_{14} \text { Bait }_{k, i, t} \text {.Water Turbidity }{ }_{k, i, t}-U_{k, i, t}+V_{k, i,}
\end{aligned}
$$

Where the output is quantity of fish caught per day, three traditional inputs are the labour, capital and bait, and the environment detrimental input is water turbidity (from sand dredging and non-dredging areas). The maximum likelihood estimator is used to estimate TE, which is modelled as a truncatednormal random variable multiplied by a specific function of time. The estimated TE is substituted in equation (9) to obtain $\mathrm{EE}$ for each fisherman in the study area.

In the second stage of this study, factors influencing EE is determined as indicated in the equation 11. Following Reinhard et al. (1999) approach, only variables that are not considered in stage one are used as shown in the equation. A two-stage least squares (2SLS) is chosen in order to determine the factors influencing EE in the study area. The choice of 2SLS is because many economic models involve endogeneity. As a general rule, when a variable is endogenous, it will be correlated with the disturbance term, hence violating the Gauss-Markov assumptions and making our Ordinary Least Squares (OLS) estimates biased (Nagler, 1999; Woodridge, 2009). This problem often arises as a result of omitted variables or measurement error in variables associated with data collection. Instrumental Variable (IV) estimator (TwoStage Least Squares) method is designed to handle the consequences of omitted variables (or measurement error) unlike OLS (the test is based on the hypothesis below). Also 2SLS is preferred to the more conventional Maximum Likelihood (ML) method for Structural Equation Model (SEM) because it does not require any distributional assumptions for RHS independent variables; they can be non-normal, binary among others (Oczkowski, 2003)

$$
\begin{aligned}
& H_{o}: \operatorname{Cov}\left(y_{2}, u\right)=0,\left(\hat{\beta}^{\text {oLS }} \text { and } \hat{\beta}^{2 S L S} \text { are consistent but } \hat{\beta}^{\text {oLS }} \text { is more efficient }\right) \\
& H_{1}: \operatorname{Cov}\left(y_{2}, u\right) \neq 0,\left(\text { only } \hat{\beta}^{2 S L S} \text { is consistent }\right)
\end{aligned}
$$


The instrumented variables (dredging status, distance covered by fishermen, experience in fishing and educational status of fisherman) are contained in the equation (11) below:

However, it should be noted that other socio economic variables are not considered among the variables influencing EE because problem of the detrimental input (water turbidity) goes beyond what a fisherman's age, household size, marital status and gender can influence. It is the expertise of the fishermen and the condition of the environment that may influence EE.

$$
E E_{c}=\delta_{0}+\delta_{1} \ln \phi_{1}+\delta_{2} \ln \phi_{2}+\delta_{3} \ln \phi_{3}+\delta_{4} \ln \phi_{4}+U \ldots \ldots(11)
$$

Where:

$\mathrm{EE}_{\mathrm{C}}$ represents the quantity of environmental efficiency

$\phi_{1}$ represents status of fishing site (Dredging site $=1$, Non-Dredging site $=0$ )

$\phi_{2}$ represents distance covered $(\mathrm{km})$ while fishing

$\phi_{3}$ represents experience in fishing (year)

$\phi_{4}$ represents the educational status of respondent (Educated $=1$, no formal education $=0$ )

$\delta$ represents vectors of parameter to be estimated

$U$ represents error component

The instruments are age, gender, marital status, household size, other economic activities and price per kilogramme of fish caught.

\subsection{Cost and Return Analysis}

Having determined the environmental efficiency of the fishermen in the study area, the cost and return analyses associated with fishermen in the nondredging and sand dredging areas are estimated. Various cost items (variable and fixed) incurred by respondents in the two areas (dredging and nondredging) are identified. The contribution of fixed items to fishing activity per day is determined using straight line method of depreciation (see equation 12). Gross profit of fishermen in dredging and non-dredging sites is estimated using equation (13). The costs of the following fixed items, namely locally made Canoe, paddle, net, basket, trap and rope are considered for each fisherman in the dredging and non-dredging areas. Bait is the only variable item used by the artisanal fishermen.

$$
\text { Depreciation Value }(N)=\frac{\text { Cost of the item }(N)}{\text { Economic life span }(\text { year })}
$$


Average Gross Profit (AGP) $=$ TR - TC

Where:

$$
\begin{aligned}
& \text { AGP }=\text { Average Gross Profit }(\mathrm{N}) \\
& \mathrm{TR}=\text { Total Revenue }(\mathrm{N}) \\
& \mathrm{TC}=\text { Total Cost }(\mathrm{N}) \\
& \text { Total Re venue }(\mathrm{TR})=\text { PQ } \ldots \ldots \ldots
\end{aligned}
$$

Total Cost $(\mathrm{TC})=$ Total Fixed Cost + Total Variable Cost

Where:

$$
\begin{aligned}
& \mathrm{P}=\text { price }(\mathrm{N}) \text { per } \mathrm{kg} \text { of fish } \\
& \mathrm{Q}=\text { the quantity of fish sold }
\end{aligned}
$$




\subsection{Results and Discussion}

\subsection{Descriptive analysis}

This subsection profiles the socioeconomic characteristics of fishermen in the study areas. These are the age, marital status, educational status, household size, experience in fishing among others. These characteristics are considered for all respondents (fishermen); respondents in the non-dredging and dredging areas.

The result reveals that $91.1 \%$ of the respondents are male. This confirms earlier studies that artisanal fishing is a male dominated economic activity (Anyanwu et al., 2009; George et al., 2012; Solomon and Kerere, 2013). Women are more involved in fish marketing and processing (Mafimisebi et al.2013). Also majority (33.5\%) of the respondents falls within the age bracket of 34 - 43years (see Figure 8.0) while the average age is 43.9years. Most respondents in the non-dredging (31.4\%) and dredging (42.2\%) sites are within the age bracket of 44 - 53 and 34 - 43years respectively (see figure 8.0). These age brackets are the economically active ages of human population. However, the result shows that there is no significant difference in the average ages of fishermen in non-dredging and dredging areas ( $p>0.05)$.

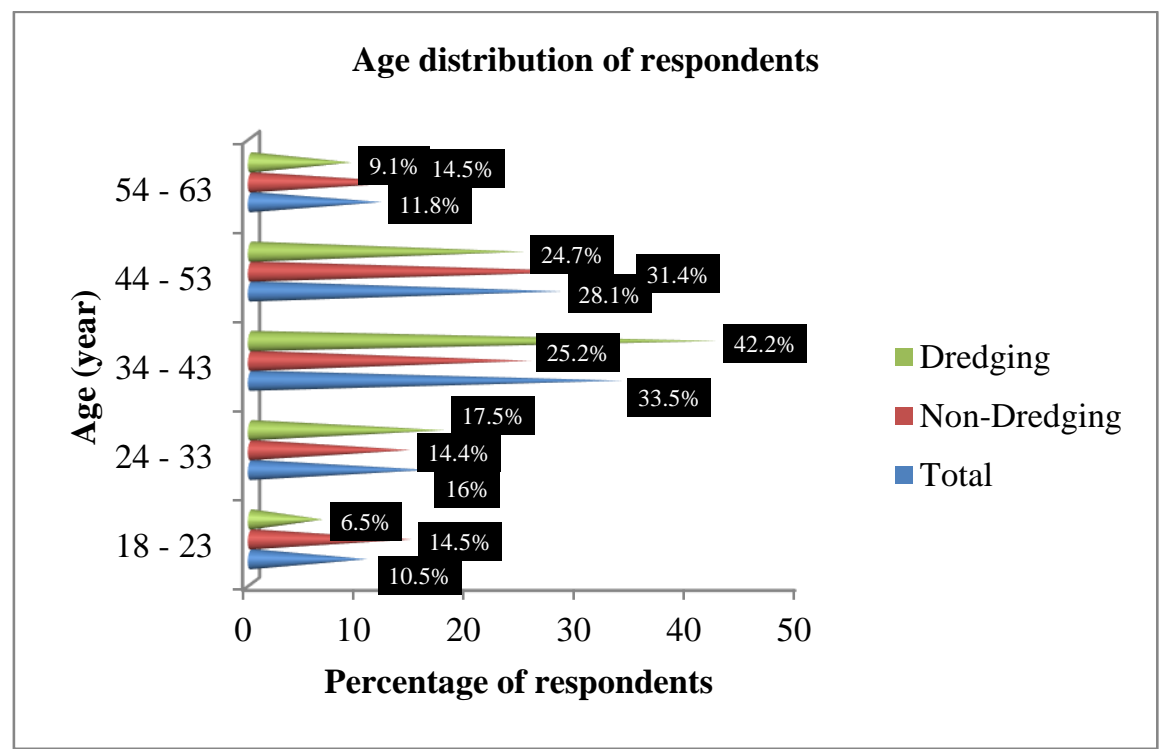

Figure 8.0: Age distribution of respondents

Also, the result reveals that $70.6 \%$ of the total respondents are married. $64.2 \%$ and $77.3 \%$ are married among fishermen in non-dredging and dredging sites 
respectively. From the result, there are more married fishermen in the dredging areas. Moreover, more than half of the respondents can read and write in the two sites. However, the level of literacy is marginally higher in the sand dredging areas (71\%) compared with non-dredging areas (69\%). The level of education among the educated fishermen and women ranges from Primary School Leaving Certificate to Ordinary National Diploma (OND). The average household size among all the respondents is 7.9 while the value is higher (8.6) among the respondents in non-dredging areas compared with sand dredging areas (7.2). There is also statistical significant difference in household size between respondents in non-dredging and dredging areas $(\mathrm{p}<0.01)$ (see table 1.0). The average household sizes in the two locations are more than the national average household size (5.2) and the average household size of Lagos state (3.8) (NBS, 2012). This confirms high population among the fishing communities in the study area which encourages overexploitation of fish in order to meet up with food need of households.

Table 1.0: Descriptive statistics by fishing site

\begin{tabular}{|c|c|c|c|c|c|c|c|}
\hline \multirow[t]{2}{*}{ Output and Input } & \multicolumn{2}{|c|}{ Total 313} & \multicolumn{2}{|c|}{$\begin{array}{l}\text { Non-dredging } \\
\text { Site (161) }\end{array}$} & \multicolumn{2}{|c|}{$\begin{array}{c}\text { Dredging site } \\
\text { (152) }\end{array}$} & \multirow{2}{*}{$\begin{array}{c}\text { Equalities } \\
\text { p-value }\end{array}$} \\
\hline & Mean & Sd & Mean & sd & Mean & sd & \\
\hline Quantity caught (g) & 8054.3 & $\begin{array}{l}2866 . \\
3\end{array}$ & 7250.2 & $\begin{array}{l}2345 . \\
3\end{array}$ & 8959.4 & $\begin{array}{l}3076 . \\
9\end{array}$ & 0.000 \\
\hline Labour -hour (hr) & 4.2 & 2.4 & 2.1 & 1.1 & 6.4 & 2.0 & 0.000 \\
\hline Capital ( () & 255.2 & 152.4 & 281.9 & 174.4 & 227.6 & 120.3 & 0.001 \\
\hline Bait (N) & 122.2 & 37.5 & 123.1 & 35.3 & 121.4 & 40.0 & 0.683 \\
\hline Water Turbidity (NTU) & 79.9 & 77.8 & 23.3 & 17.1 & 139.9 & 71.7 & 0.000 \\
\hline \multicolumn{8}{|l|}{ Household characteristics } \\
\hline Experience in fishing (year) & 16.5 & 6.7 & 16.5 & 7.1 & 16.6 & 6.2 & 0.888 \\
\hline Age (year) & 43.9 & 11.5 & 44.3 & 12.6 & 43.6 & 10.1 & 0.597 \\
\hline Marital status & 0.7 & 0.5 & 0.6 & 0.5 & 0.8 & 0.4 & 0.011 \\
\hline Household size & 7.9 & 3.1 & 8.6 & 3.0 & 7.2 & 3.1 & 0.000 \\
\hline Educational status & 0.7 & 0.5 & 0.69 & 0.46 & 0.71 & .46 & 0.759 \\
\hline Other economic activities & 0.45 & 0.5 & 0.5 & 0.5 & 0.4 & 0.5 & 0.057 \\
\hline \multicolumn{8}{|l|}{ Area characteristics } \\
\hline Distance covered $(\mathrm{km})$ & 6.8 & 6.7 & 2.4 & 2.3 & 11.4 & 6.7 & 0.000 \\
\hline
\end{tabular}

Note: For all tests of means, the null hypothesis is that the no significant difference in the variables. The confidence level chosen is $5 \%$.

The high household size is typical of peasant farmers generally (Bester et al., 1998; Asogwa et al., 2014). They believe that large family assist in farming as shown in this result where $95.8 \%$ of the fishermen relied on family labour.

Table 1.0 shows that for all the respondents, the average quantity of fish caught per day is $8.05 \mathrm{~kg}$ with the standard deviation of approximately $2.9 \mathrm{~kg}$. 
Moreover, the quantity of fish caught in the dredging area $(8.9 \mathrm{~kg})$ is significantly $(\mathrm{p}<0.01)$ greater than that of the non-dredging area $(7.3 \mathrm{~kg})$. This may be attributed to the long distance travelled by fishermen whose communities are in the sand dredging vicinity in order to fish. Their survival as well as their family depends on the fish caught per day. However, these quantities in relation to labour hour shows that fishermen in non-dredging areas are more labour-hour efficient. Specifically, fishermen in the nondredging areas caught $3.45 \mathrm{~kg}$ of fish per labour hour compared with $1.4 \mathrm{~kg}$ per labour hour for fishermen in dredging areas.

According to Tawari (2002), fishermen move in fulfilment of their occupation. They move in search of fish as dictated by the type of fish required and the movement of the tide which may be caused by sand dredging. The average distance covered by fishermen in the sand dredging area is significantly greater than that of fishermen in non-dredging area (see table 1.0). Travelling longer distance to places where the effect of dredging is minimal may be their copy strategy since their livelihood depends on the fish caught per day. Also, the result shows that apart from travelling longer distance, fishermen whose community is located in the vicinity of sand dredging spent longer hours fishing $(\mathrm{p}<0.01)$. Table 2.0 shows the distribution of sand dredging duration as at the time data for the study were collected.

Majority of the fishermen (45.2\%) claimed that sand dredging has been taking place in their community from $6-10$ years while less than $1 \%$ claimed at least 21 years. The average sand dredging duration is 7.05years with the standard deviation of approximately 5years. This means that on the average, high water turbidity which accompanied sand dredging has been persisting in the sand dredging areas for more than seven years. Also, the varying duration may determine the number of times that fishermen have to travel long distance from their base in order to avoid the negative effect of sand dredging.

Table 2.0: Distribution of sand dredging duration (year)

\begin{tabular}{ccc}
\hline $\begin{array}{c}\text { Dredging Duration } \\
\text { (year) }\end{array}$ & Number of respondent (s) & Percentage of respondent (s) \\
\hline $0.5-5$ & 64 & 43.8 \\
$6-10$ & 66 & 45.2 \\
$11-15$ & 5 & 3.4 \\
$16-20$ & 10 & 6.8 \\
$21 \&$ above & 1 & 0.7 \\
\hline
\end{tabular}

Source: Author's computation 
The fixed items used in production are un-motorized canoe, paddle, net, basket, knife and plastic bowls. The contribution of each of these items to the fish caught per day was determined using straight line method of depreciation and the number of days each fisherman work per week. The result shows that respondents (fishermen) at non-dredging areas spent on average $\$ 281.90$ on fixed capital per day while respondents having their community in the vicinity of sand dredging areas spent $\$ 227.62$ per day. Fishermen in the non-dredging areas incurred higher amount on fixed capital because they spent more on local traps that are set in their surroundings ( $\mathrm{p}<0.01)$. These (traps) are checked frequently unlike the fishermen that travel longer distance from their community. Also, fishermen in the no-dredging areas invest more in new unmotorized boats.

Moreover, bait was the only variable item the fishermen used. This is common in environment where common property theory is in place. Like forest product gatherers, artisanal fishermen continuously exploit the natural resources without adding anything in return. Increase in population increases the pressure on the exploitation of natural resources. Figures 9.0a and b show the small-size fish caught. The small sizes of fish may be attributed to over exploitation occasioned by large household size among fishermen. Same reason may be given for fishermen engaging in other economic activities such as barbing, vulcanizing, tailoring, bricklaying, security among others to complement their little income from fishing. From the result, $50.3 \%$ and $39.6 \%$ of fishermen in non-dredging and dredging areas respectively are engaging in other economic activities. 


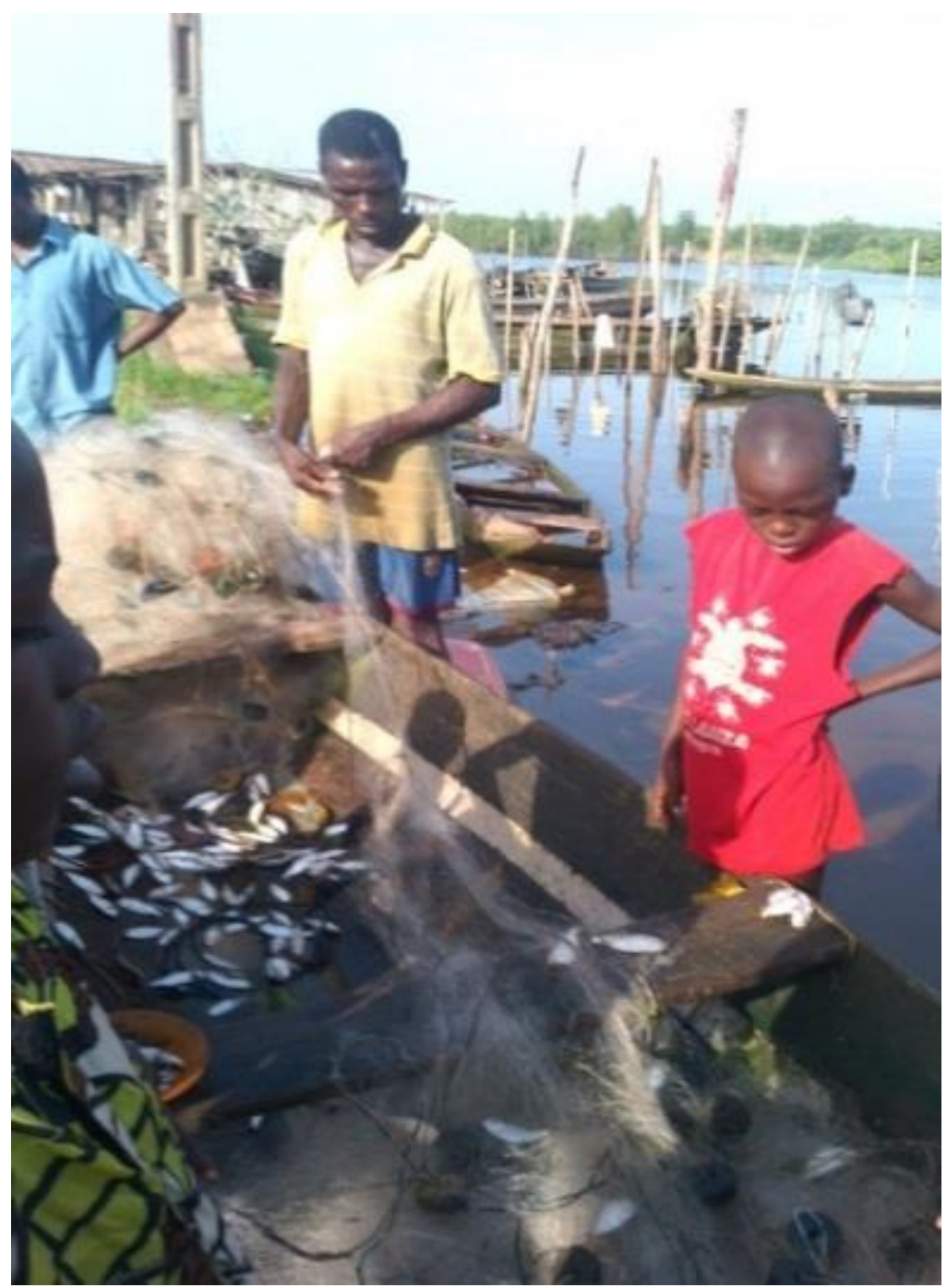

Figure 9.0a: A fisherman and his children looking disappointed at the sizes of fish caught at Majidun. 


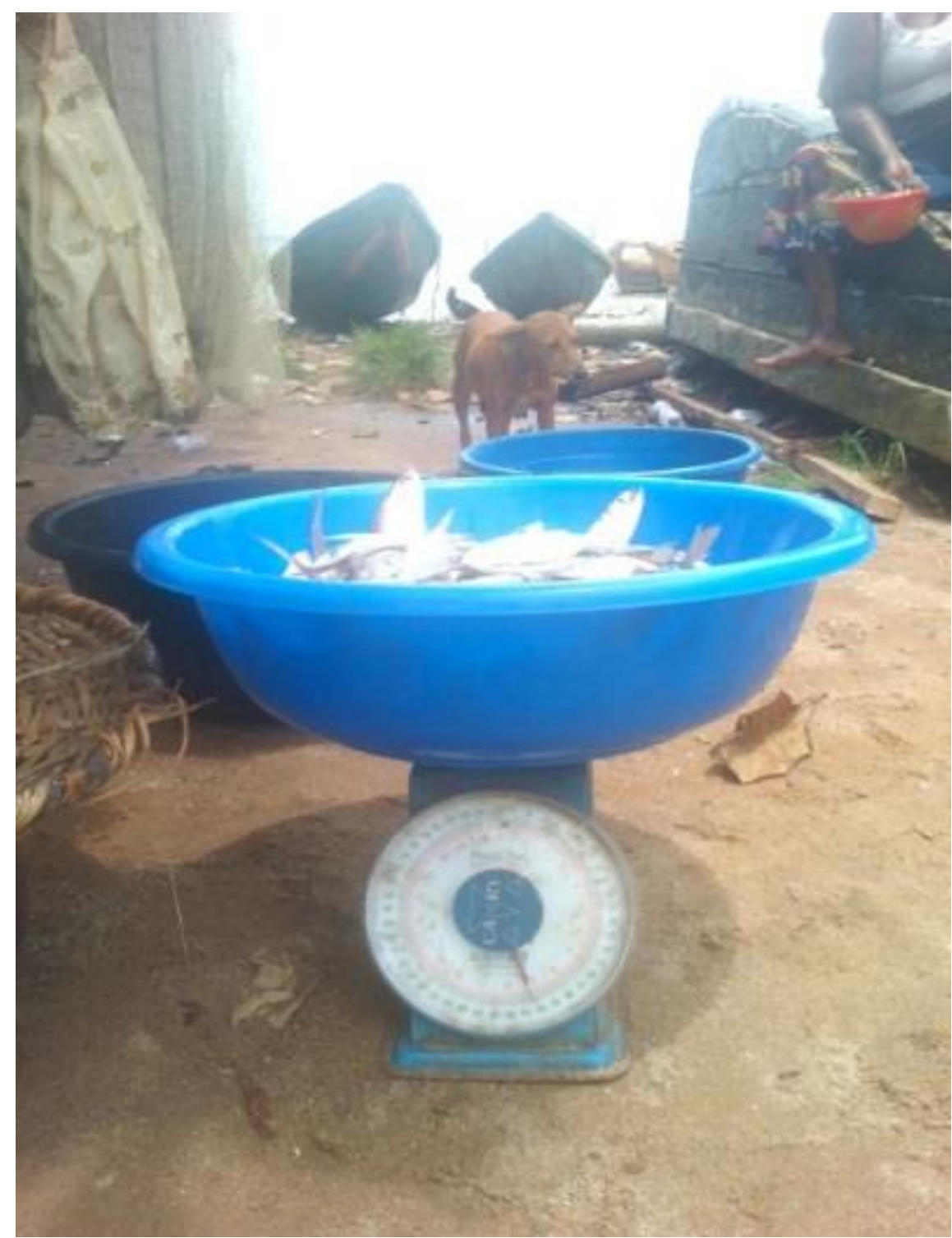

Figure 9.0b: Weighing of the fish caught

\subsection{Determination of Environmental Efficiency (EE) from Stochastic Frontier Approach (SFA) model}

In order to obtain the EE of the artisanal fishermen, the coefficients and the residuals obtained from stochastic production frontier model are substituted in equation (9). The stochastic production frontier model is shown in table 3.0. The estimation of EE is preceded by ascertaining the theoretical consistency of the estimated efficiency model. The need for the marginal productivity of inputs to be positive as stipulated in microeconomic theory is germane. 
Table 3.0: Stochastic Production Frontier model

\begin{tabular}{|c|c|c|c|c|}
\hline \multicolumn{5}{|c|}{ Dependent Variable: Quantity of fish caught per day } \\
\hline \multirow[b]{3}{*}{ Variables } & \multirow[b]{2}{*}{ (1) } & \multirow[b]{2}{*}{ (2) } & \multicolumn{2}{|c|}{ Input elasticities } \\
\hline & & & (3) & (4) \\
\hline & $\begin{array}{l}\text { Coefficient } \\
\text { estimate }\end{array}$ & $\begin{array}{l}\text { Standard } \\
\text { error }\end{array}$ & $\begin{array}{c}\text { Sample } \\
\text { mean }\end{array}$ & $\begin{array}{l}\text { Sample } \\
\text { median }\end{array}$ \\
\hline Labour-hour & $-1.358 * *$ & 0.674 & 0.371 & 0.156 \\
\hline Capital & 0.044 & 0.513 & -0.192 & -0.161 \\
\hline Bait & 0.083 & 0.665 & 0.370 & 0.386 \\
\hline Turbidity & $-0.828 *$ & 0.427 & 0.349 & 0.422 \\
\hline Labour hour square & $-1.137 * * *$ & 0.221 & & \\
\hline Capital square & -0.032 & 0.033 & & \\
\hline Bait square & 0.035 & 0.041 & & \\
\hline Turbidity square & 0.094 & 0.069 & & \\
\hline Labour hour $*$ & & & & \\
\hline Capital & $0.230 * *$ & 0.112 & & \\
\hline Labour hour * Bait & $0.404 *$ & 0.230 & & \\
\hline Labour hr * & & & & \\
\hline Turbidity & $0.385 * * *$ & 0.078 & & \\
\hline Capital * Bait & -0.068 & 0.163 & & \\
\hline Capital* Turbidity & 0.036 & 0.036 & & \\
\hline Bait * Turbidity & -0.051 & 0.066 & & \\
\hline Intercept & $10.922 * * *$ & 3.256 & & \\
\hline Sample size & 313 & & & \\
\hline Log - likelihood & -52.642 & & & \\
\hline $\begin{array}{l}\text { Sigma-Squared } \\
\left(\sigma^{2}\right)\end{array}$ & $0.242 *$ & & & \\
\hline $\operatorname{Gamma}(\gamma)$ & $0.848 * * *$ & & & \\
\hline $\mathrm{Mu}(\mu)$ & $-0.320 *$ & & & \\
\hline $\operatorname{Sigma}_{\mathrm{u}} 2$ & 0.206 & & & \\
\hline Sigmay2 & $0.037 * * *$ & & & \\
\hline
\end{tabular}

Estimation method: maximum likelihood estimator. Note that $* * *$ means statistical significance at $1 \%, * *$ means statistical significance at $5 \%$ and $*$ means statistical significance at $10 \%$.

Since translog functional form does not allow for the direct interpretation of the magnitude and the significance of the individual input elasticity as it is done in constant elasticity Cobb-Douglas case (Sharma and Leung, 1999; Manchard and Guo, 2014), the elasticity of each input (labour hour, capital, water turbidity and bait) is calculated at sample mean and median (see table 4) using formula ${ }^{4}$. The result (see table 3 ) shows the elasticities of all the inputs

\footnotetext{
${ }^{4}$ Following Sharma and Leung (1999) and Manchard and Guo (2014), the elasticities of mean output with respect to the $\mathrm{j}^{\text {th }}$ input variable are calculated at the mean/median of the log of the input variable and its second order coefficients as follows:
} 
that are positive at sample mean and median except capital. From the table, quantity of fish caught depends more on labour hour and bait at sample mean. The negative marginal productivity of capital may be attributed to inefficiency in the use of capital inputs due to factors (sand dredging) beyond the control of fishermen.

Furthermore, the return to scale at sample mean (0.898) and sample median (0.803) are positive. This implies that artisanal fishing in the study area is in stage II of production where daily fish caught increases at decreasing rate. The significance of $\sigma^{2}(p<0.10)$ shows the presence of inefficiency effects and random error in artisanal fishing in the study area. The gamma value shows that $85 \%$ of the variability in the quantity of fish caught by fishermen is explained by their technical inefficiency.

Within the framework of translog stochastic production frontier, I predict TE and use the coefficients from the model to calculate EE. The average of TE is 0.78 (see table 5a). The score ranges from 0.37 to 0.96 . Also, there is no significant difference in average score of TE of fishermen in the non-dredging and sand dredging areas ( $>>0.05)$. The average TE score in this study is less than what Sharma and Leung (1999) and higher than what Sesabo and Tol (2007) obtained in similar studies carried out in Hawaii and Tanzania respectively. This may be attributed to differences in method of fishing, climate and the type of fishing input used.

$\frac{\delta \ln Y}{\delta X_{j}}=\beta_{j}+2 \cdot \beta_{j j} \overline{\ln X_{j}}+\sum_{j \neq k}^{k} \beta_{j k} \overline{\ln X_{k}}$ 
Table 4.0: Descriptive statistics for the traditional and detrimental inputs

\begin{tabular}{lcccc}
\hline Parameter & Labour hour & Water Turbidity & Capital & Bait \\
\hline Mean & 1.29 & 3.87 & 5.44 & 4.76 \\
Standard Error & 0.03 & 0.06 & 0.04 & 0.03 \\
Median & 1.39 & 3.99 & 5.55 & 4.61 \\
Mode & 0.69 & 2.56 & 5.20 & 4.61 \\
Standard Deviation & 0.56 & 1.07 & 0.76 & 0.56 \\
Sample Variance & 0.31 & 1.15 & 0.58 & 0.32 \\
Kurtosis & -1.44 & -1.42 & 2.47 & 34.60 \\
Skewness & 0.19 & -0.01 & 0.36 & -2.92 \\
Range & 1.61 & 3.06 & 5.69 & 7.13 \\
Minimum & 0.69 & 2.56 & 3.26 & 0.00 \\
Maximum & 2.30 & 5.62 & 8.95 & 7.13 \\
Sum & 404.13 & 1210.97 & 1702.05 & 1489.65 \\
Count & 313 & 313 & 313 & 313 \\
\hline
\end{tabular}

Note: the inputs are in their natural logarithms.

However, the average EE in the study area is 0.31 while EEs of fishermen in non-dredging and dredging areas are 0.49 and 0.10 respectively. The result also affirms that there is significant difference in EE scores between the two areas $(p<0.01)$ (see table $5 a \& b)$. The standard error of EE is greater than that of TE. The result suggests that most fishermen are not environmentally efficient. This implies that higher TE score does not guarantee high EE score. 
Table 5.0a: Descriptive statistics for Technical and Environmental Efficiencies

\begin{tabular}{|c|c|c|c|c|c|c|}
\hline \multirow{2}{*}{ Parameter } & \multicolumn{3}{|c|}{ Technical Efficiency } & \multicolumn{3}{|c|}{ Environmental Efficiency } \\
\hline & Total & Non-dredging site & Dredging site & Total & Non-dredging site & Dredging site \\
\hline Mean & 0.776 & 0.780 & 0.772 & 0.305 & 0.497 & 0.102 \\
\hline Standard Error & 0.007 & 0.008 & 0.011 & 0.015 & 0.017 & 0.007 \\
\hline Median & 0.811 & 0.811 & 0.813 & 0.239 & 0.461 & 0.061 \\
\hline Mode & 0.788 & 0.788 & 0.803 & 0.723 & 0.723 & 0.051 \\
\hline Standard Deviation & 0.120 & 0.103 & 0.135 & 0.258 & 0.214 & 0.088 \\
\hline Sample Variance & 0.014 & 0.011 & 0.018 & 0.066 & 0.046 & 0.008 \\
\hline Kurtosis & 0.514 & 1.662 & -0.219 & -0.797 & -1.305 & 1.353 \\
\hline Skewness & -1.080 & -1.344 & -0.888 & 0.695 & 0.110 & 1.406 \\
\hline Range & 0.587 & 0.499 & 0.587 & 0.941 & 0.883 & 0.401 \\
\hline Minimum & 0.371 & 0.413 & 0.371 & 0.001 & 0.060 & 0.001 \\
\hline Maximum & 0.959 & 0.913 & 0.959 & 0.942 & 0.942 & 0.402 \\
\hline Sum & 243.005 & 125.588 & 117.417 & 95.536 & 80.014 & 15.522 \\
\hline Count & 313 & 161 & 152 & 313 & 161 & 152 \\
\hline
\end{tabular}

Author's calculation 
Table 5.0b: Equality test for technical and environmental efficiencies

\begin{tabular}{llcccccc}
\hline \multirow{2}{*}{ Parameter } & \multicolumn{2}{c}{ Total 313 } & \multicolumn{2}{c}{ Non-dredging } & \multicolumn{2}{c}{ Dredging site } & \multirow{2}{*}{ Equalities } \\
& Mean & Sd & Mean & sd & Mean & sd & P-value \\
\cline { 2 - 8 } & 0.776 & 0.120 & 0.790 & 0.101 & 0.780 & 0.103 & 0.549 \\
Technical Efficiency & 0.305 & 0.262 & 0.497 & 0.214 & 0.102 & 0.088 & 0.000 \\
Environmental Efficiency & & & & & &
\end{tabular}

The distribution of EE score in Figure 10.0 shows $65.1 \%$ of the fishermen in sand dredging area have EE score ranging from 0.001 to 0.099 while only $0.6 \%$ of the fishermen in non-dredging area are in this category. Also, 29.8\% and $5.3 \%$ of fishermen in the non-dredging and sand dredging areas respectively are within the environmental efficiency score of $0.31-0.50$. Only $2.5 \%$ of the fishermen in non-dredging area have EE score of 0.91-0.99. Generally, the result shows a very low EE scores among fishermen in the dredging area. The solution for the control of the detrimental input (water turbidity) that will bring about increase in EE score is beyond the control of individual fisherman or group of fishermen.

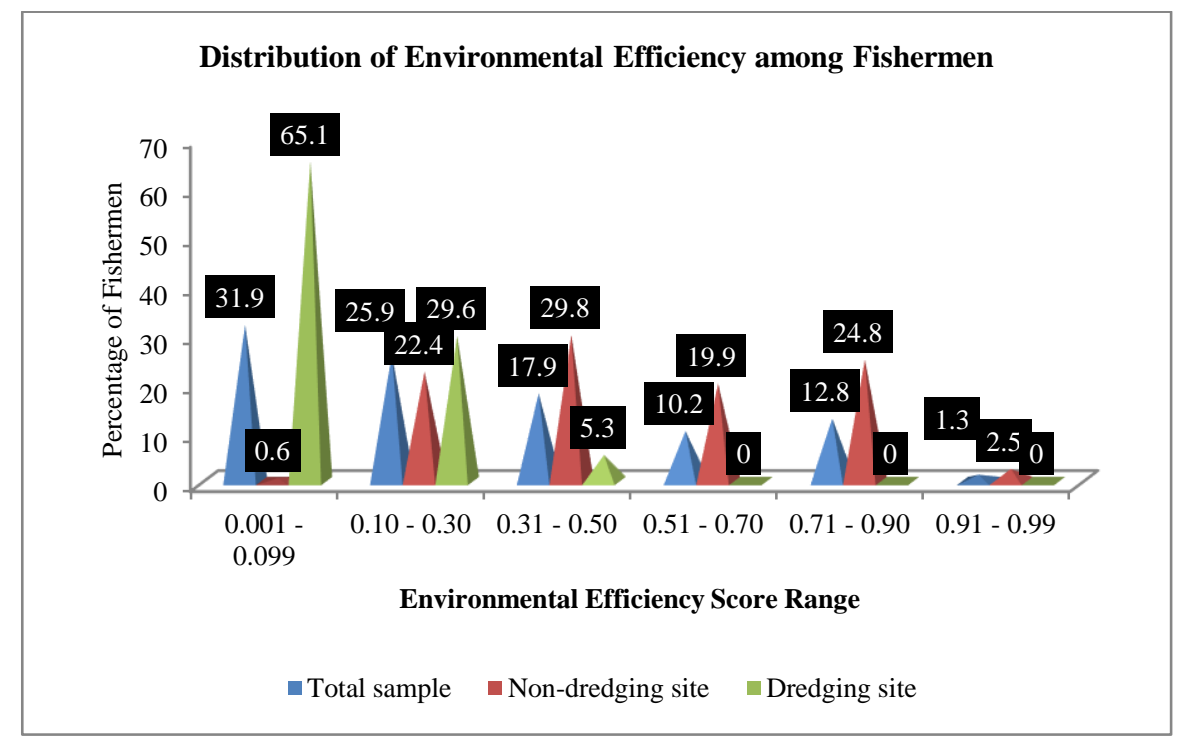

Figure 10.0: Distribution of Environmental Efficiency among Fishermen

This is unlike in crop farm where nitrogen or sulphur in the soil may be a detrimental input; all that is required is to control the amount of this nutrient in the soil through organic/inorganic fertilizer. 


\subsection{Determinants of Environmental Efficiency}

The Hausman's endogeneity test reveals that the parameter of 2SLS is consistent $(\mathrm{p}<0.01)$, hence it is preferred to OLS. However, the results of the two analyses are shown in table 6.0. The result (2SLS) shows that dredging status (Dredging area $=1$, non-dredging=0), experience in fishing (year) and educational status of fisherman significantly influence environmental efficiency. Specifically, the result reveals that sand dredging has a negative causal relationship with environmental efficiency. That is, sand dredging reduces environmental efficiency of fishermen. This result supports the earlier result that shows that environmental efficiency is generally low in sand dredging (0.10) areas and by extension affects the quantity of the fish caught by the fishermen in the dredging area.

Table 6.0: Determinants of Environmental Efficiency

\begin{tabular}{lllll}
\hline & \multicolumn{2}{c}{ OLS Estimator } & \multicolumn{2}{c}{ 2SLS Estimator } \\
\hline Parameter & Coefficient & Sd error & Coefficient & Sd error \\
& & & & \\
\hline Const & $0.4159^{* * *}$ & 0.0326 & $0.1978^{*}$ & 0.1136 \\
dreStat & $-0.3672^{* * *}$ & 0.0248 & $-0.4109^{* * *}$ & 0.1337 \\
Discov & $-0.0035^{*}$ & 0.0019 & -0.0097 & 0.0115 \\
Expyr & $0.0055^{* * *}$ & 0.0014 & $0.0141^{* * *}$ & 0.0034 \\
Edstat & 0.0042 & 0.0203 & $0.2044^{* * *}$ & 0.0786 \\
\hline Sample size & 313 & & 313 & \\
Adjusted $\mathrm{R}^{-2}$ & 0.6182 & & 0.5419 & \\
F Statistics & 127.2711 & & 23.9126 & \\
Hausman & & & 28.6691 & \\
Statistics & & & & \\
Hausman p-value & & & & \\
\hline
\end{tabular}

Source: Author's computation

However, as a coping strategy and in order to fish, the fishermen usually move far away from their base where dredging is taking place. The result also shows that experience in fishing $(\mathrm{p}<0.01)$ and educational status $(\mathrm{p}<0.01)$ are significant and positively related to environmental efficiency. That is, education and experience of fisherman increase environmental efficiency.

\subsection{Breakdown of costs and returns of Fishermen in the study area}

Table 7.0 shows the breakdown of the various costs incurred per day as well as the average daily revenue of fishermen in the study area. The table reveals that fishermen in the dredging area incurred higher cost per day. This may be attributed to cost incurred on long distance travelled to catch fish in order to 
avoid dredging area. Fishermen in the non-dredging area incurred more cost on canoe, trap and net. Specifically, the higher cost on locally made trap may be due to their closeness to the fishing water which gives them opportunity to inspect the trap easily. This is unlike fishermen residing in the sand dredging areas that have to travel a long distance to fish. However, the fishermen in the sand dredging area spent more on miscellaneous items (knife, plastic bowl among others).

Generally, average total cost per day for fishermen in the sand dredging area is higher than that of non-dredging area. However, the average daily revenue from fish is higher among fishermen in the sand dredging areas (see table 7). The distance travelled away from the dredging site for fishing and the smaller household size may be attributed to higher quantity of fish caught and the revenue accruable. However, fishermen in non-dredging areas have higher returns from other economic activities. From table 7.0, the average gross profit per day is higher among the fishermen in the non-dredging areas. However, the average per capita gross profit is higher among fishermen in the dredging areas. This may be attributed to smaller average household size among fishermen in the dredging areas. While overexploitation (large household size) alone may be the reason for small per capita gross profit among fishing households in the non-dredging area, it is the combination of overexploitation and dredging activities in the sand dredging area.

Table 7.0: Breakdown of costs and return for fishermen

\begin{tabular}{lccc}
\hline \multirow{2}{*}{ Items } & \multicolumn{3}{c}{ Average amount (N) } \\
\cline { 3 - 4 } Fixed cost per day & $\begin{array}{c}\text { Total Sample } \\
\text { Site (313) }\end{array}$ & $\begin{array}{c}\text { Non-dredging } \\
\text { site (161) }\end{array}$ & $\begin{array}{c}\text { Dredging } \\
\text { site (152) }\end{array}$ \\
\cline { 2 - 4 } Canoe & 152.34 & 156.46 & 148.22 \\
Paddle & 5.21 & 5.52 & 4.84 \\
Net & 81.48 & 90.32 & 72.02 \\
Basket & 4.57 & 4.21 & 4.85 \\
Trap & 5.68 & 7.26 & 4.1 \\
Rope & 6.68 & 6.93 & 6.58 \\
Miscellaneous (knife, plastic & 19.11 & 11.2 & 16.99 \\
bowl/bucket etc) & 65.96 & 23.28 & 110.58 \\
\hline Cost of distance covered (km) & 341.03 & 305.18 & 368.18 \\
\hline Average total fixed cost & 122.24 & 123.24 & 122.81 \\
\hline Variable cost & $\mathbf{3 7 7 . 4 4}$ & $\mathbf{4 0 5 . 1 4}$ & $\mathbf{3 5 0 . 4 1}$ \\
Bait & & &
\end{tabular}




\begin{tabular}{lccc}
$\begin{array}{l}\text { Average revenue per day } \\
\text { from fish }\end{array}$ & $4,309.94$ & $3,952.88$ & $4,695.08$ \\
\hline $\begin{array}{l}\text { Revenue accruable for extra } \\
\text { hours (other economic } \\
\text { activities) }\end{array}$ & 660 & 1290.00 & - \\
\hline $\begin{array}{l}\text { Average gross profit per day } \\
\text { Average Household size }\end{array}$ & $\mathbf{4 , 6 2 8 . 9 1}$ & $\mathbf{4 , 9 3 7 . 7 0}$ & $\mathbf{4 , 3 2 6 . 9 0}$ \\
\hline $\begin{array}{l}\text { Average per capita gross } \\
\text { profit }\end{array}$ & $\mathbf{7 . 9}$ & $\mathbf{8 . 6}$ & $\mathbf{7 . 2}$ \\
\hline $\begin{array}{l}\text { Source: Autho's computation } \\
\text { nan }\end{array}$ & 585.94 & 574.15 & 600.96 \\
\hline
\end{tabular}

Source: Author's computation

Overexploitation is the result of increasing population encouraged by common property theory. The average per capita gross profit is far below the national per capita income of $\$ 1,339.72$ per day (The Guardian Global Development Professional Network, 2014) $)^{5}$. Hence, the need for fishermen to engage in the rearing of fish in their respective communities to complement what they are getting presently.

${ }^{5}$ Per capita income of $\$ 3000$ ( $\$ 489,000$ at $\$ 1=\mathrm{N} 163$ ). This is equivalent to $\$ 1,339.72$ 


\subsection{Conclusion and Recommendation}

\subsection{Conclusion}

The study examined the environmental and economic burden of sand dredging on artisanal fishing in Lagos state in Nigeria. Findings revealed that the fishing communities are exploiting the shortcomings of common property theory. Most especially, the large population which encourages over exploitation of fish as confirmed by the sizes of fish caught. The study also showed that $45.2 \%$ of the fishermen indicated that dredging has been going on in their communities in the last 6-10years.

It was revealed that sand dredging has a negative effect on the environmental efficiency of fishermen. The negative effect of sand dredging on environmental efficiency captured by water turbidity was more pronounced in the sand dredging fishing communities. Sand dredging, educational status, distance covered for fishing were identified as factors influencing environmental efficiency of fishermen in the study area. The negative effect of sand dredging did not manifest in environmental efficiency alone but also in the average gross profit of the fishermen. The fishermen in the non-dredging areas incurred less cost and higher gross profit. The finding attributed the low per capita gross profit (lower than national per capita income) among the fishermen in non-dredging areas to mainly overexploitation (large household size) while dredging and overexploitation are the reasons for small per capita gross profit among fishermen in sand dredging areas.

The study affirmed that fishermen residing in the dredging vicinity adopted moving far away from dredging site in order to fish as their major coping strategy. Apart from being stressful, it may hasten the depreciation fixed inputs, such as canoe and paddle. However, while this study has been able to include environmental factor as production input; environmental inefficiency among the fishermen may not be attributed to just one environmental factor (water turbidity). One environmental factor was used due to data limitations.

\subsection{Recommendations}

In order to bring about harmonisation between sustainability of natural resources and human survival, the following are recommended based on the findings of the study:

1. The activities of the dredging firms should be properly monitored by government by ensuring that dredging license is not issued indiscriminately. That is, government should ensure that vicinities of 
fish producing communities are not licenced for dredging. This will not only reduce the environmental degradation but also help to sustain the aquatic habitat.

2. The need for the artisanal fishermen to be properly integrated into government's Agricultural Transformation Agenda (ATA) is imperative. Not only by assisting them with fishing inputs but also by encouraging fishermen to rear fish or engage in other agricultural venture suitable to their environment (example is swampy rice). This will go a long way in addressing overexploitation and also help to improve their per capita income.

3. The family planning unit of the Ministry of Health at Lagos state could ensure that their activity in the fishing communities is intensified. This will not only help to reduce the household size but also reduces overexploitation of aquatic animals.

4. The fishery department of the Ministry of Agriculture could also ensure that fishing nets used by fishermen are of sizeable mesh that will allow small fish to grow to the table size before being caught. This can be achieved through periodic inspection.

\section{References}

Adesina, E. M. and Ayanda, J. O. (2001). Fishery management plans and the development of artisanal fisheries in nigeria: A review. Retrieved from aquaticcommons.org/3988/1/219.pdf

Adesoji, S. A. and Kerere, F. O. (2013): Assessment of the knowledge level of fishers and fish farmers in Lagos State, Nigeria. International Journal of Knowledge, Innovation and Entrepreneurship, vol. 1 Nos. 1-2, 2013, pp. 41-56

Aigner, D., Lovell, C. and Schmidt, P. (1977): Formulation and estimation of stochastic frontier production models, Journal of Econometrics, vol.6, pp. $21-37$

Alam, F., (2011): Measuring technical, allocative and cost efficiency of pangas (Pangasius hypophthalmus: Sauvage 1878) fish farmers of Bangladesh. Aquaculture Research, 42(10):1487-1500.

Anchor Environmental LLC (2003). Literature review of effects of resuspended sediments due to dredging operations. iii+87 pp.+App. A-C. June. Prepared for Los Angeles Contaminated Sediments Task Force. 
Anyanwu, D. C. Mkpado, M. and Ohaka, C. C. (2009). Economic analysis of artisanal fishing at River Niger. Journal of Tropical Agriculture, Food, Environment and Extension, 8(3), 175-179.

Ask. com (2014). What is sand dredging? Available on www.ask.com

Asogwa, B. C., Abu, O. and Ochoche, G. E. (2014): Analysis of Peasant Farmers' Access to Agricultural Credit in Benue State, Nigeria. British Journal of Economics, Management \& Trade, vol. 4(10), pp. 15251543.

Bada, A. S. (2005). Strategies for Bridging the Supply-Demand Gap in Fish Production in Nigeria. Proceedings of the $19^{\text {th }}$ Annual Conference of the Farm Management Association of Nigeria, pp. 329-337.

Balogun, I. (2011): Sand miners eroding fishermen's livelihood. Available on http://www.vanguardngr.com/2011/04/sand-miners-erodingfishermen\%E2\%80\%99s-livelihood/\#sthash.jEomIY2b.dpuf

Battese, G. E. and Coelli, T. J. (1988): Prediction of Grm-level technical efficiencies: With a generalized frontier production function and panel data. Journal of Econometrics, vol. 38, pp. 387 - 399

Battese, G. E. and Coelli, T. J. (1992). "Frontier Production Functions, Technical Efficiency and Panel Data: With Application to Paddy Farmers in India." Journal of Productivity Analysis 3, 153-169.

Bester, B. J., Belete, A. and Kelembe, S. G. (1998): Assessing Peasant Farmers' Risk Attitudes and Factors that Influence Decisions on Risky Alternatives: A Case Study in the Border Region of South Africa. Agrekon, vol. 37(3).

Boyd, C. E. (1984): Water Quality in warm water fish ponds. Auburn University, Auburn.

Brantz von Mayer (2011). Dredgers and Dredging. Available on: http://www.dredgebrokers.com/HTML/Dredging/Dredging.html

Brian, C. (nd): Riverine Gravel Mining in Washington State, Physical Effects with Implications for Salmonid Habitat, and Summary of Government Regulations. Report prepared for: U.S. Environmental Protection Agency 1200 Sixth Avenue Seattle, WA 98101 Completion report for Grant X-000694-01-0

Brown, A. V., Lyttle, M. M. and Brown, K. B., (1998). Impacts of gravel mining on gravel bed streams. Transactions of the American Fisheries Society, 127, pp. 979-994.

Burczynski, J. (1991). Hydroacoustic survey of fish distribution and reaction to dredge disposal activities in San Francisco Bay. Final Report. [vi]+19pp.+app.A-B. BioSonics, Inc., Seattle, WA. February 21.

Chansang, H. (1988): Coastal Tin Mining and Marine Pollution in Thailand. Ambio., vol. 17, pp. 223 - 228. 
Christensen, L. R., Jorgenson, D. W. and Lau, L. J. (1971): Conjugate duality and the transcendental logarithmic function. Econometrica, vol. 39(4).

Cone, L. D. (1995). A review of the potential impacts of mechanical harvesting on subtidal and intertidal shellfish resources. Marine Resources Research Institute, SC Department of Natural Resources, Charleston, SC.

Coglan, L., Pascoe, S., and Mardle, S. 1998. DEA versus econometric analysis of efficiency in fisheries. In Paper prepared for the Proceedings of the 9th International Conference of the International Institute of Fisheries Economics and Trade (IIFET) Tromsø, Norway, 1998. Ed. by A. Eide, and T. Vassdal. IIFET, Troms $\emptyset$, Norway.

Collins, B. 1995. Riverine gravel mining in Washington state, overview of effects on salmonid habitat, and a summary of government regulations. Unpublished report to the US EPA, Seattle.

Committee on Ecosystem Effects of Fishing (2002). Effects of Trawling and Dredging on Seafloor Habitat. Retrieved from http://www.nap.edu/catalog.php?record_id=10323

Dankwa, H. R., Biney, C. A. and deGraft-Johnson (2005): Impact of Mining Operations on the Ecology of river Offin in Ghana. West African Journal of Applied Ecology, vol.7.

Dredge, Drill \& Haul (2009): The Changing Dredging Scene. Available on http://www.ddhmag.com/2ndqtr09editorial.htm

Dredging - Wikipedia, the free encyclopedia, (2014)

Economic Analysis of Environmental Issues (2005). Common-Property Resources and Public Goods. Available on www.ase.tufts.edu/gdae/publications/textbooks/jhtext_ch04.pdf

Ekeke, B. A, Davies, O. A. and Alfred-Oekiya, J. F. (2008): Sand Dredging on the fish catch in Bonny River Estuary, Nigeria. Environmental Research Journal, vol. 2(6), pp. 299-305.

Everhart, W. H. and Duchrow, R. M., (1970). Effects of suspended sediment on aquatic environments. U.S. Bur. Reclam. Proj. Compl. Rpt., Colo. St. Univ., Fort Collins, CO. vi[?]+106pp. March.

Fare, R. and Primont, D. (1995): Multi-Output Production and Duality: Theory and Applications. Boston: Kluwer Academic Publishers.

Färe, R., Grosskopf, S. Lovell, C.A.K and Pasurka, C. (1989), Multilateral Productivity Comparisons When Some Outputs are Undesirable: a Nonparametric Approach. The Review of Economics and Statistics 71:1 (February), 90-98.

Färe, R., Grosskopf, S., Lovell, C.A.K. and Yaisawarng, S. (1993), "Derivation of Shadow Prices for Undesirable Outputs: a Distance Function Approach". The Review of Economics and Statistics 75:2 (May), 374-380. 
Farrell, M. J. (1957): The measurement of productive efficiency. Journal of the Royal Statistical Society, A CXX, 253-290.

Fischer, J. R. and Paukert, C. P. (2009): Effects of sampling effort, assemblage similarity, and habitat heterogeneity on estimates of species richness and relative abundance of stream fishes. Canadian Journal of Fisheries and Aquatic Sciences 66 (2), 277-290

Fish for All Summit (2005). Presentation of Nigeria's Fisheries Resources, Abuja, Nigeria 22-25 August 2005.

Food and Agriculture Organisation (2008): Marine Fishery Resources of Nigeria: A review of exploited fish stocks. Available http://www.fao.org/docrep/003/R9004E/R9004E00.HTM

Forsage, A. and Carter, N. E., (1973). Effects of gravel dredging on the Brazos River. Proceedings of the Annual Conference of Southern Associations of Fish and Game Commissioners, vol. 28, pp. 695-709.

Frid, C. L. J. and Clark, R. A., (2000). Long-term changes in North Sea benthos: Discerning the role of fisheries. In Effects of Fishing on Non-Target Species and Habitats: Biological, Conservation, and Socio- Economic Issues, Kaiser, M.J. and S.J. de Groot (eds.). Blackwell Science, Oxford.

George, F., Odulate, D. and Idowu, A. (2012): Climate change effects and adaptation strategies in a Nigerian coastal Agro-ecological zone. A paper presented at $2^{\text {nd }}$ International Symposium on effects of Climate Change on the World's Oceans, May $13-20,2012$, Yeosu, South Korea.

Gordon, H. S. (1954). The economic theory of a common-property resource: the fishery. Journal of Political Economy, vol. 62, pp.124-42.

Graham, M. (2004): Environmental Efficiency: Meaning and Measurement and Application to Australian. Available On Www. Ageconsearch.Umn.Edu/Bitstream/58450/2/2004_Graham.Pdf

Greenstreet, S. P. R. and Hall, S. J., (1996). Fishing and groundfish assemblage structure in the northwestern North Sea: An analysis of long-term and spatial trends. Journal of Animal Ecology, vol. 65, pp. 577-598.

Guo, H. and Marchand S. (2012): The environmental efficiency of organic farming in developing countries: a case study from China. Serie Etudes et Documents Du Cerdi (CERDI). Etudes et Documents no.38. Novembre 2012

Hay, D. E., and McKinnell, S. M. (2002). Tagging along: association among individual Pacific herring (Clupea pallasi) revealed by tagging. Canadian Journal of Fisheries and Aquaculture Science, vol. 59, pp.1960-1968. 
Idowu E. T., Amaeze N. H., Adie P. I. and Otubanjo O. A. (2014): Heavy metal bioaccumulation and biomarkers of oxidative stress in the wild African tiger frog, Hoplobatrachus occipitalis. African Journal of Environmental Science and Technology, vol. 8(1), pp. 6-15.

Idowu, A. A. (2010): Effect of some socio-economic activities on fish diversity of lagoon systems in Ogun waterside Local Government of Ogun State, Nigeria. Int. J. Biol. Chem. Sci. 4(1): 88-99.

Igben, J. L. (2014): Inland Sand Dredging and Economic Activities in the Niger Delta, Nigeria. Sacha Journal of Environmental Studies, vol. 4 (1), pp. 1-7

International Fund for Agricultural Development (IFAD). Calculating the Sample Size. Available on http://www.ifad.org/gender/tools/hfs/anthropometry/ant_3.htm

Kareem, R. O, Idowu, E.O, Ayinde, I. A. and Badmus, M. A. (2012): Economic Efficiency of Freshwater Artisanal Fisheries in Ijebu Waterside of Ogun State, Nigeria. Global Journal of Science Frontier Research, Vol. 12(11).

Kim, Y. T., H. J. Kim, and G. H. Lee. 2008. Mechanical behaviour of lightweight soil reinforce with waste fishing net. Geotextiles and Geomembranes, vol. 26, pp. 512-518.

Klacek, J., Vosvrda, M. and Schlosser, S. (2007): "KLE Production Function and Total Factor Productivity", in Statistika, No. 4.

Kondolf, G. M. (1997). Hungry water: effects of dams and gravel mining on river channels. Environmental Management, 21:533-551.

Khumbhakar, S. C. and Heshmatic, A. (1995): Efficiency Measurement in Swedish Dairy Farms: An Application of Rotating Panel Data 19761988. American Journal of Agricultural Economics, 77(3): 660-674.

Kumbhakar, S. and Lovell, C. (2000): Stochastic Frontier Analysis, Cambridge.

Lake, P. S. (1990). Disturbing hard and soft bottom communities: A comparison of marine and freshwater environments. Australian Journal of Ecology, vol. 15, pp. 477-489.

LaSalle, M. W. 1990. Physical and Chemical Alterations Associated with Dredging: An Overview. pp. 1-12 in: Simenstad, C. A. (ed.), Effects of Dredging on Anadromous Pacific Coast Fishes. Workshop Proceedings, Seattle, September 8-9, 1988. [v]+160pp. Wash. Sea Grant Prog., Univ. Wash., Seattle, WA.

Levine, F. (2004): Framework for Assessment of Potential Effects of Dredging on Sensitive Fish Species in San Francisco Bay. Prepared for U.S. Army Corps of Engineers San Francisco District, San Francisco, California 
Mafimisebi, T. E., Ikuemonisan, E. S. and Mafimisebi, O. E. (2013): Comparative Profitability of Women Dominated Fish-Based Livelihood Activities in Southwest, Nigeria. Available on https://genderaquafish.files.wordpress.com/2013/04/ppt_01.pdf

Marchand, S. and Guo, H. (2014): The environmental efficiency of noncertified organic farming in China: A case study of paddy rice production. China Economic Review, 31, 201-216.

McFarland, V. A., C. H. Lutz, and F. J. Reilly. 1989a. Factors influencing bioaccumulation of sediment-associated contaminants by aquatic organisms: factors related to sediment and water. 9pp. Environ. Eff. Dredg. Tech. Notes EEDP-01-18. US Army Waterways Exp. Stat., Vicksburg, MS. July.

McFarland, V. A., C. H. Lutz, and F. J. Reilly. 1989b. Factors influencing bioaccumulation of sediment-associated contaminants by aquatic organisms: factors related to biota. 6pp. Environ. Eff. Dredg. Tech. Notes EEDP-01-19. US Army Waterways Exp. Stat., Vicksburg, MS. July.

Meador, M. R. and. Layher, A. O., (1998). Instream sand and gravel mining: environmental issues and regulatory process in the United States. Fisheries, 23(11), pp. 6-13.

Meeusen, W. and van den Broeck, J. (1977), Efficiency estimation from Cobb-Douglas production functions with composed error, International Economics Review, vol.18, no.2, pp.435-444.

Messieh, S. N., Wildish, D. J. and Peterson, R. H., (1981). Possible impact from dredging and spoil disposal on the Miramich Bay herring fishery. Canadian Technical Report of Fisheries and Aquatic Science 1008. iv + 33 pages. April.

Mmom, P. C. and Chukwu-Okeah, G. O. (2012): Sand Dredging and River Morphology Change along Parts of New Calabar River in Akpor Area of Rivers State, Nigeria and its Implications for Biological Resource Conservation. Research Journal of Environmental and Earth Sciences 4(1): 82-87, 2012

Moore, P. G. (1977). Inorganic particulate suspensions in the sea and their effects on marine animals. Oceanography and Marine Biology Annual Review 15:225-363.

Muhammad Aqeel Ashraf1, Mohd. Jamil Maah1 Ismail Yusoff, Abdul Wajid and Karamat Mahmood (2011): Sand mining effects, causes and concerns: A case study from Bestari Jaya, Selangor, Peninsular Malaysia. Scientific Research and Essays. vol. 6(6), pp. 1216-1231, 18 March, 2011 
Nagler, J. (1999): Notes on Simultaneous Equations and Two Stage Least Squares Estimates. Available on http://www.nyu.edu/classes/nagler/ quant $2 /$ notes/2slsnotes_oh.pdf

National Bureau of Statistics (2012): Social Statistics in Nigeria. Available on www.nigerianstat.gov.ng/pages/download/168

Nayar, S., Miller, D. J., Hunt, A., Goh, B. P. L., \& Chou, L. M. (2007). Environmental effects of dredging on sediment nutrients, carbon and granulometry in a tropical estuary. Environmental Monitoring and Assessment, 127(1-3), 1-13. doi:10.1007/s10661-006-9253-2

Nkwoji, J. A., Onyema I. C. and Igbo, J. K. (2010): Wet Season Spatial Occurrence of Phytoplankton and Zooplankton in Lagos Lagoon, Nigeria. Science World Journal, vol. 5 (2)

Nnodim, O. (2014). Nigeria spends N125bn annually on fish importation. The Punch. Retrieved from http://www.punchng.com/news/nigeriaspends-n125bn-on-fish-import-annually-fg/

O'Connor, J. M. (1991): Evaluation of turbidity and turbidity-related effects on the biota of the San Francisco Bay-Delta Estuary. viii+84pp. San Francisco Estuary Institute, Richmond, CA. Report submitted to U.S. Army Engineers, San Francisco District.

Oczkowski, E. (2003): Two-Stage Least Squares (2SLS) and Structural Equation Models (SEM). Available on http://csusap.csu.edu.au/ eoczkows/home.htm

Odunaike, K., J.A. Laoye, Adeniyi, T. L. P. Akinyemi, L. P. and Adeyeloja, A. (2013): Physico-Chemical Characterization Of Water Samples at Egbin Thermal Station in Ijede and its Environs in Lagos State Of Nigeria. Journal of Environment and Earth Science, vol.3(14).

Ogunniyi, L. T., Ajao, A.O and Sanusi, W.A. (2012): Technical Efficiency in Artisanal Fisheries (AF) in Badagry Local Government Area of Lagos State, Nigeria. Continental J. Fisheries and Aquatic Science 6 (1): 1 8,2012

Okoruwa, V. O., Sowunmi, F. A., Ogundele, F. O. and Omigie, C. O. (2014): Resource - Use Efficiency: An Application of Stochastic Frontier Production Function to Plantain Farmers in Ogun State, Nigeria. Journal of Economics and Sustainable Development. vol. 5(21), pp. $114-127$.

Okoruwa, V.O., and Ogundele, O. O. (2006): Technical Efficiency Differentials In Rice Production Technologies In Nigeria.

Available on www.csae.ox.ac.uk/conferences/2006-EOI-RPI/papers/ .../ Okoruwa.pdf

Oliveira, M. M., Camanho, A. S., and Gaspar, M. B. 2010. Technical and economic efficiency analysis of the Portuguese artisanal dredge fleet. - ICES Journal of Marine Science, 67: 1811-1821. 
Olomola, A. S. (1993). The traditional approach towards sustainable management of common property fishery resources in Nigeria. Marine Anthropology Studies, vol. 6(1/2), pp. '92-109.

Olomola, S. A. (1998). Sources and Resolution of Conflicts in Nigerian Artisanal Fisheries. Society and Natural Resources, vol. 11, pp.121135.

Organisation for Economic Co-Operation and Development (1997): Environmental Indicators for Agriculture: Concepts and framework. Available on http://www.oecd.org/greengrowth/sustainableagriculture/40680795.pdf

Pascoe, S., and Tingley, D. 2006. Economic capacity estimation in fisheries: a non-parametric ray approach. Resource and Energy Economics, 28: 124-138.

Pauket, C., Schloesser, J., Fischer, J. and Eitzmann, J. (2008). Effect of Instream Sand Dredging on Fish Communities in the Kansas River USA: Current and Historical Perspectives. Journal of Freshwater Ecology, 23(4).

Pavelescu, F. (2011): Some Aspects of the Translog Production Function Estimation. Institute of National Economy, Romanian Academy. Available On www.revecon.ro/articles/2011-1/2011-1-8.pdf

Pickett, S. T. A. and White, P. S., (1995). The Ecology of Natural Disturbance and Patch Dynamics. Academic Press, New York, NY.

Pittman, R. W. (1983) "Multilateral Productivity Comparisons with Undesirable Outputs." Economic Journal 93 (372): 883-91

Ramilan, T., Scrimgeour, F. and Marsh, D. (2011): Analysis of environmental and economic efficiency using a farm population micro-simulation model. Mathematics and Computers in Simulation, vo. 81(7), pp. 1344-1352

Reinhard, S. (1999): Econometric analysis of economic and environmental efficiency of Dutch dairy farms. A Ph.D. Thesis, Wageningen Agricultural University.

Reinhard, S., Knox Lovell, C. A. and Thijssen, G. J. (2000): Environmental efficiency with multiple environmentally detrimental variables; estimated with SFA and DEA. European Journal of Operational Research, 121, 287-303

Reinhard, S., Lovell, C. A. K., Thijssen, G., 1999. Econometric estimation of technical and environmental efficiency: An application to dutch dairy farms. American Journal of Agricultural Economics 81 (1), 44-60.

Rivers and Coast. (2010). Shallow Water Dredging. Centre for Coastal Resources Management, 5(1), 1-8. 
Sesabo, J. K. and Tol, R. S. J. (2007): Technical efficiency of small scale fishing households in Tanzanian Coastal Villages: an empirical analysis. African Journal of Aquatic Science, vol. 32(1), pp. 51 - 61.

Sharma, K. R. and Leung, P. S. (1999): Technical efficiency of the longline fishery in Hawaii: An Application of Stochastic Production Frontier. Marine Resource Economics, vol. 13, pp. 259-274.

Shehu, J. F., Iyortyer, J. T., Mshelia, S. I. and Jongur, A. A. U. (2010): Determinants of Yam Production and Technical Efficiency among Yam Farmers in Benue State, Nigeria. Journal of Social Science, 24(2): 143-148 (2010).

Sigler, J. W. (1990). Effects of chronic turbidity on anadromous salmonids: Recent studies and assessment techniques perspectives. p 26-37 In: C. A. Simenstad (ed.). Effects of dredging on anadromous Pacific Coast fishes: workshop proceedings. University of Washington Sea Grant Program, Seattle, Washington.

Simenstad, C. A. (ed.). 1990. Effects of dredging on anadromous Pacific coast fishes: workshop proceedings. University of Washington Sea Grant Program, Seattle, Washington.

Solomon, A. A. and Kerere, F. O. (2013): Assessment of the knowledge level of fishers and fish farmers in Lagos State, Nigeria. International Journal of Knowledge, Innovation and Entrepreneurship, vol. 1 (1-2), pp. $41-56$

Squires, D., Grafton, R.Q., Alam, M.F.and Omar, I.H.,(2003).Technical efficiency in the Malaysian gill net artisanal fishery. Environment and Development Economics, 8(03):481-504.

Starnes, L. B., and Gasper, D. C., (1996). Effects Of Surface Mining on Aquatic Resources in North America. Fisheries, 21(5): 24-26.

Stevenson, R. E. (1980). "Likelihood functions for generalized stochastic frontier estimation." Journal of Econometrics 13, 57-66.

Sustainable Fisheries Livelihoods Programme (SFLP) (2002). Committee on Fisheries Research Joint Working Party on Poverty in Small-Scale Fisheries: Promoting the Contribution of the Sustainable Livelihoods Approach and the Code of Conduct for Responsible Fisheries in Poverty alleviation, Rome, 10 - 12 April, 2002. Issue 678 of FAO fisheries report, Food and Agriculture Organization,

Tae Goun Kima, Thomas A. Grigalunasa, Kyung-Nam Hanb (2008): The economic costs to fisheries because of marine sand mining in Ongjin Korea: Concepts, methods, and illustrative results. Ecological Economics, vol.6 5, pp. $498-507$

Tamini, L. D., Larue, B. and West, G. (2011): Technical and environmental efficiencies and best management practices in agriculture. Applied Economics, vol. 44(13), pp. 1659-1672. 
Tawari, F. (2002): Dissemination of Research Findings on Nomadic Education in Nigeria (The Migrant Fishermen Education Experience): Issues and Directions; at the International Conference organised by International Extension College (IEC) Cambridge and Sponsored by the Department for International Development (DFID) at Rock View Hotel Abuja-Nigeria 16th - 19th January.

The Guardian Global Development Professional Network (2014). Nigeria becomes Africa's largest economy. Available on http://www.theguardian.com/globaldevelopment/datablog/2014/apr/0 7/nigeria-becomes-africa-largest-economy-get-data

Tillin, H. M., Houghton, A. J., Saunders, J. E., Drabble, R. and Hull, S. C., (2011). Direct and Indirect Impacts of Aggregate Dredging. Marine Aggregate Levy Sustainability Fund (MALSF). Science Monograph Series: No. 1.

Tingley, D., Pascoe, S., and Coglan, L. 2005. Factors affecting technical efficiency in fisheries: Stochastic Production Frontier versus Data Envelopment Analysis approaches. Fisheries Research, 73: 363-376.

U.S. Army Corps of Engineers (2004). Framework for Assessment of Potential Effects of Dredging on Sensitive Fish Species in San Francisco Bay. Final Report.

U.S. Environmental Protection Agency (1995). Sector notebook project: profile of the non-fuel, non-metal mining industry. EPA, Office of Compliance, Washington, D.C.

U.S. Environmental Protection Agency and U.S. Army Corps of Engineers.(1992). "Evaluating environmental effects of dredged material management alternatives - a technical framework." EPA-842B-92-008. http://www.epa.gov/OWOW/oceans/framework.

University Press, Cambridge.

Van Meensel J., Lauwers L. Van Huylenbroeck G. and Van Passel S. (2010): Comparing frontier methods for economic-environmental trade-off analysis. European Journal of Operational Research, vol. 207, pp.1027-1040

Vinyard, G. L. and W. J. O'Brien. 1976. Effects of light and turbidity on reactive distance of bluegill (Lepomis macrochirus). Journal of the Fisheries Research Board of Canada 33:2845-2849.

Wikipedia, free encyclopedia. (2014). Artisan fishing. Retrieved from en.wikipedia.org/wiki/Artisan_fishing

Wilber, C. G. (1983). Turbidity in the aquatic environment: An environmental factor in fresh and oceanic waters. Charles Thomas Publications, Springfield, IL.

Wilber, D. H. and Clarke, D. G., (2001). Biological effects of suspended sediments: a review of suspended sediment impacts on fish and 
shellfish with relation to dredging activities in estuaries. North American Journal Fish Management, vol. 21, pp. 855-875.

Whitehead, G. J. (2007): Land and environment: sand mining. Available on http://localhistory.kingston.vic.gov.au/htu.

Wooldridge, J. M. (2009): Introductory Econometrics, 4th edition, South Western-Cengage.

Yen, T. P. and Rohasliney, H. (2013): Status of Water Quality Subject to Sand Mining in the Kelantan River, Kelantan. Tropical life science research 2013, 24(1), $19-34$

\section{Appendix}

\section{Sample size}

The sample size $(453.6 \cong 450)$ used for the study is obtained using IFAD procedure based on the formula below. The final sample size made allowances for design effect (1.5) and contingency (5\%). The allowance for design effect is expected to correct for the difference in design while allowance for contingency account for contingencies such as non- response or recording error.

$$
\mathrm{n}=\frac{\mathrm{t}^{2} \mathrm{p}(1-\mathrm{p})}{\mathrm{m}^{2}} \ldots \ldots \ldots \ldots \ldots \ldots \ldots(1)
$$

Where:

$\mathrm{n}=$ the sample size

$\mathrm{t}=$ confidence level at $95 \%$ (1.96)

$p=$ estimated percentage of artisanal fishermen out of fishermen population in Lagos state $(75 \%)$. $\mathrm{m}=$ margin error $(5 \%$ or 0.05$)$ 
UNITED NATIONS

UNIVERSITY

UNU-INRA

Institute for Natural Resources in Africa

\section{Contact Details}

United Nations University Institute for Natural Resources in Africa

(UNU-INRA)

Second Floor, International House,

Annie Jiagge Road, University of Ghana, Legon

Accra, Ghana

Private Mail Bag,

Kotoka International Airport, Accra, Ghana

Tel: +233-302- 213850. Ext. 6318

Email: inra@unu.edu

Website: www.inra.unu.edu
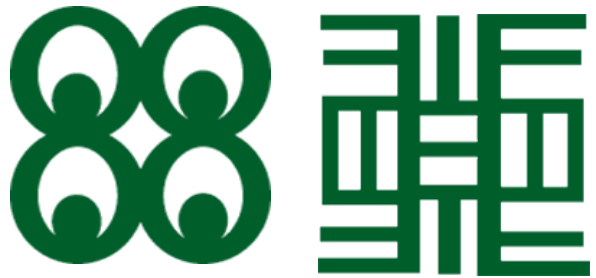

MATE MASIE

\section{NEA ONNIMNO SUA}

A, OHU

"What I hear, I keep"-Symbol of wisdom, knowledge and understanding.
"He who does not know can know from learning, -Symbol of life-long education and continued quest for knowledge.

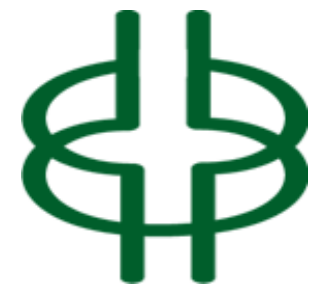

ISBN: 978-9988-633-08-0

NYANSAPO

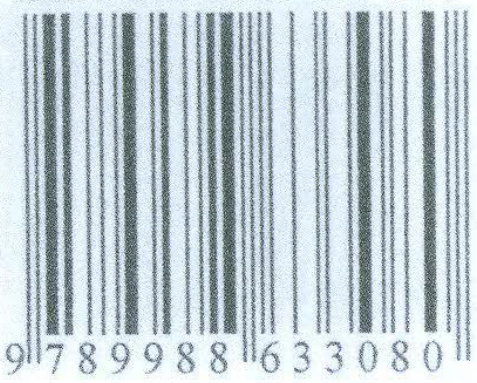

